\title{
Multidimensional Intersection of Nicotine, Gene Expression, and Behavior
}

\author{
Yasmine Sherafat, Malia Bautista and Christie D. Fowler* \\ Department of Neurobiology and Behavior, University of California, Irvine, Irvine, CA, Unites States
}

The cholinergic system plays a crucial role in nervous system function with important effects on developmental processes, cognition, attention, motivation, reward, learning, and memory. Nicotine, the reinforcing component of tobacco and e-cigarettes, directly acts on the cholinergic system by targeting nicotinic acetylcholine receptors (nAChRs) in the brain. Activation of nAChRs leads to a multitude of immediate and long-lasting effects in specific cellular populations, thereby affecting the addictive properties of the drug. In addition to the direct actions of nicotine in binding to and opening nAChRs, the subsequent activation of circuits and downstream signaling cascades leads to a wide range of changes in gene expression, which can subsequently alter further behavioral expression. In this review, we provide an overview of the actions of nicotine that lead

\section{OPEN ACCESS}

Edited by:

Luis Miguel Tuesta, University of Miami, United States

Reviewed by: Andrew Tapper, University of Massachusetts Medical School, United States Ryan Logan, Boston University, United States

*Correspondence: Christie D. Fowler cdfowler@uci.edu

Specialty section: This article was submitted to Learning and Memory, a section of the journal Frontiers in Behavioral Neuroscience

Received: 03 January 2021 Accepted: 24 February 2021 Published: 22 March 2021

Citation:

Sherafat $Y$, Bautista $M$ and Fowler CD (2021) Multidimensional Intersection of Nicotine, Gene

Expression and Behavior. Front. Behav. Neurosci. 15:649129. doi: 10.3389/fnbeh.2021.649129 to changes in gene expression and further highlight evidence supporting how these changes can often be bidirectional, thereby inducing subsequent changes in behaviors associated with further drug intake.

Keywords: nicotine addiction, nicotine withdrawal, nicotinic acetylcholine receptor (nAChR), gene expression, endogenous allosteric modulator, epigenetics, acetylcholine

\section{INTRODUCTION}

The cholinergic system exerts widespread actions in multiple brain regions to regulate developmental processes, cognition, attention, motivation, reward, sleep, learning, and memory (Lindstrom, 1997; Picciotto et al., 2002; Blake and Boccia, 2018; Mu and Huang, 2019; Fowler et al., 2020; Gipson and Fowler, 2020). Deficits in cholinergic signaling are found to result in a broad range of negative impacts on cognitive processes, such as that found with Alzheimer's disease, Parkinson's disease, and other cognitive disorders (Lindstrom, 1997; Picciotto and Zoli, 2002). In the central nervous system, the endogenous neurotransmitter, acetylcholine, is released from axon terminals in all main subdivisions of the brain (Guo et al., 2015; Fowler et al., 2020). Acetylcholine acts on two main receptor subclasses, nicotinic acetylcholine receptors (nAChRs) and muscarinic acetylcholine receptors (mAChRs). The downstream effects of receptor activation not only modulate immediate behavioral and cognitive effects but also lead to downstream effects on gene expression.

Nicotine is an alkaloid derived from the tobacco plant and when consumed, acts as a full agonist on the nAChRs (Changeux et al., 1998; Picciotto et al., 2008). Tobacco cigarettes and e-cigarettes contain high levels of nicotine, which infer a high addiction liability through actions on nAChRs in the reward-related systems in the brain. Activation of nAChRs by nicotine leads to both similar and different actions as that found with acetylcholine, depending on the method of administration, dose, and frequency of exposure 
(McGehee et al., 1995; Picciotto et al., 2008; Chen et al., 2020; Fowler et al., 2020; Wittenberg et al., 2020). Moreover, in addition to changes in the brain, it should also be noted that long-term effects of nicotine are found in other organ systems, such as the lungs (Ariyoshi et al., 2002; Amos et al., 2008; Garcia-Arcos et al., 2016; Sun et al., 2017; Kyte and Gewirtz, 2018; Liu et al., 2018), although such peripheral actions of nicotine will not be reviewed further herein. In this review, we provide an overview of nicotine's brain region and cell-typespecific actions on gene expression, and we further explore the bidirectional relationship between nicotine consumption and changes in gene expression.

\section{NICOTINE'S ACTIONS ON CHOLINERGIC SIGNALING MECHANISMS}

After release from the presynaptic terminal, acetylcholine binds to either mAChRs or nAChRs, depending on the receptor localization across cell types in the brain. Both receptors are involved in the autonomic nervous system, nociception, cognition, and learning and memory processes (Changeux et al., 1998; Yagi et al., 2015; Thomsen et al., 2018; Javadi-Paydar et al., 2019). The nAChRs are ionotropic, allowing for the influx of $\mathrm{Na}^{2+}$ and $\mathrm{Ca}^{+}$and efflux of $\mathrm{K}^{+}$during the receptor's open conformational state following ligand binding (Lipsius, 1982; Fuentealba et al., 2004). In contrast, activation of the metabotropic mAChRs leads to G-protein mediated secondmessenger signaling cascades (Haga, 2013). The mAChR exhibits five different subtypes (M1-M5; Hulme et al., 1990). M2 and M4 subtypes couple with Gi/Go proteins, whereas M1, M3, and M5 subtypes couple with Gq proteins (Haga et al., 2012). While nicotine acts directly on the nAChRs, but not the mAChRs, it appears that both receptor classes may modulate processes underlying drug addiction. For instance, a recent human GWAS study found that allelic variation in the M2 gene, CHRM2, is associated with nicotine dependence in women (Mobascher et al., 2010). Interestingly, activation of M2 mAChRs mediates aspects of pain perception, which is dysregulated in individuals with nicotine dependence (Wess et al., 2007; Al'Absi et al., 2015). These findings suggest a possible indirect link between nicotine, pain regulation, and $\mathrm{mAChR}$ signaling. Alternatively, nicotine-mediated changes in cholinergic levels (e.g., via nAChR localization on presynaptic terminals that modulate acetylcholine release) could impact endogenous volume transmission of acetylcholine within discrete brain areas, leading to altered activity at dendritic mAChRs (Yamasaki et al., 2010).

\section{Nicotinic Acetylcholine Receptors}

In the brain, nAChRs are expressed on both neuronal and non-neuronal cells. These receptors are membrane-bound proteins from the Cys-loop family of the pentameric ligandgated ion channels superfamily, which includes the serotonin 5-hydroxytryptamine type 3 receptor, 1-aminobutyric acid type A receptor, and glycine receptor (Deba et al., 2018). As noted above, neuronal nAChRs can be expressed at either postsynaptic membranes or presynaptic terminals, and thus, $\mathrm{nAChR}$ activation can exert broad actions on multiple systems via modulation of neurotransmitter release from the synaptic terminal (Le Novère and Changeux, 1995; Mansvelder and McGehee, 2000; Deba et al., 2018). Heteromeric nAChRs are composed of a combination of $\alpha$ and $\beta$ subunits, which can include $\alpha 2-\alpha 7$ and $\beta 2-\beta 4$, and $\alpha 7 \mathrm{nAChR}$ subunits can also combine to form a homomeric receptor (Le Novère and Changeux, 1995). The different subunits co-assemble to generate a wide variety of receptor subtypes with diverse patterns of expression across cell populations, and the specific combinations of $\alpha$ and $\beta$ subunits can result in differences in ligand binding, $\mathrm{Ca}^{2+}$ permeability, and desensitization kinetics (Wang and Sun, 2005; Lipovsek et al., 2014; Pankratov and Lalo, 2014; Corradi and Bouzat, 2016; Zdenek et al., 2019). For example, in the ventral tegmental area (VTA), a variety of different $\mathrm{nAChR}$ subtypes have been proposed, which includes $\alpha 4 \alpha 5(\beta 2)_{2},(\alpha 4)_{2}(\beta 2)_{3}$, $(\alpha 4)_{2}(\beta 2)_{3}$, and $\alpha 7$ (Klink et al., 2001). Moreover, based on the specific localization within brain circuits, the effects of $\mathrm{nAChR}$ activation may lead to differing effects on behavior, which can be evidenced with nicotine self-administration; providing access across a range of doses leads to an inverted U-shaped dose-response curve that is indicative of both the reinforcing and aversive actions of the drug at the different doses (Fowler and Kenny, 2011; Fowler et al., 2011). Specifically, when nicotine doses increase from low to moderate, animals increase their responding to obtain more drug administrations, but in contrast, when doses increase from moderate to high, a decrease in responding is evidenced that is indicative of both aversion and satiation. Interestingly, the aversive properties of nicotine at higher doses are also evidenced by an increase in brain reward thresholds above baseline levels, as assessed with intracranial self-stimulation (Kenny, 2007; Fowler et al., 2011, 2013). The reinforcing and aversive properties of nicotine have been shown to involve opposing brain pathways, which are discussed in the following sections.

\section{Nicotine's Actions on Brain Circuits Underlying Addiction}

The reinforcing effects of nicotine are mediated by activation of the VTA, leading to increased dopaminergic signaling in the nucleus accumbens (NAcc; Picciotto, 1998; Rice and Cragg, 2004; Kenny and Markou, 2006; Mahler et al., 2019). The $\alpha 4$ and $\beta 2 \mathrm{nAChR}$ subunits are expressed on the majority of dopaminergic and GABAergic neurons in the VTA and have been shown to modulate nicotine-evoked currents and reinforcing properties of the drug (Picciotto et al., 1998; Tapper et al., 2004; Changeux, 2010). For instance, knockout of $\alpha 4, \alpha 6$ or $\beta 2 \mathrm{nAChR}$ subunits in mice results in a failure to self-administer nicotine, which can be rescued by re-expression of these nAChR subunits in the VTA (Picciotto et al., 1998; Pons et al., 2008). Given that the $\alpha 4, \alpha 6$ and $\beta 2$ nAChRs can combine to form a functional $\mathrm{nAChR}$ subtype, it has been postulated that nicotine's actions on the $\alpha 4 \alpha 6 \beta 2 \mathrm{nAChRs}$ in the VTA-NAcc circuit control the reinforcing properties of the drug (Picciotto et al., 1998; Kenny and Markou, 2006; Pons et al., 2008; McGranahan et al., 2011). In contrast, the $\alpha 7 \mathrm{nAChR}$ subtype appears to modulate the fine-tuning of nicotine-mediated dopamine response with lower levels of expression on VTA neurons, as 


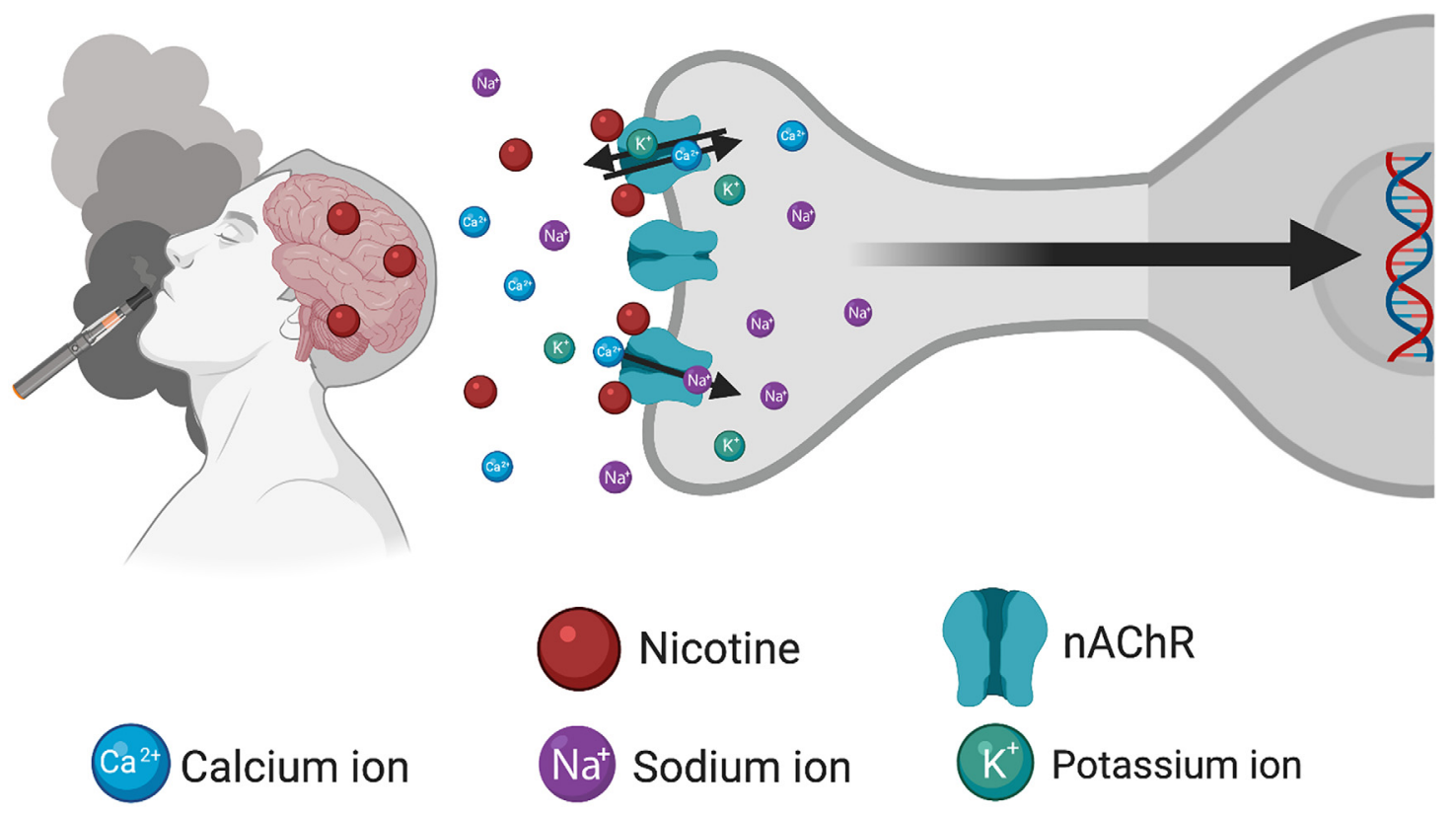

FIGURE 1 | Schematic illustrating the consequences of inhalation of nicotine from tobacco/e-cigarette products to induce changes in gene expression. After entry into the brain, nicotine binds to and activates nicotinic acetylcholine receptors (nAChRs) located on the cellular membrane, thereby inducing an open conformational state permitting the influx of $\mathrm{Ca}^{2+}$ and $\mathrm{Na}^{+}$ions and efflux of $\mathrm{K}^{+}$ions. Subsequent changes in gene expression occur through the modulation of downstream signaling cascades. Created with BioRender.com.

well as via localization on presynaptic glutamatergic terminals in the VTA (Jones and Wonnacott, 2004; Mameli-Engvall et al., 2006; Nashmi and Lester, 2006). Neurons in the VTA receive input from brain regions including the prefrontal cortex (PFC), amygdala, bed nucleus of the stria terminalis, tegmental nuclei, and local GABAergic interneurons (Theile et al., 2008; Mao et al., 2011), indicating multiple levels of modulation for integrative processing with the putative localization of nAChRs on axon terminals from some of these circuits. Cholinergic interneurons in the NAcc also play an important role in nicotineseeking behavior (Leyrer-Jackson et al., 2020). Of note, chronic administration of nicotine enhances the functional connectivity between the cortex and NAcc during cue presentation with reward learning and has also been shown to increase NMDA signaling in the PFC-NAcc circuit (Ávila-Ruiz et al., 2014; Wang et al., 2020), thereby providing evidence of behavioral and circuit level changes in reward-related processing with nicotine use.

In opposition to the mesolimbic behavioral effects, the medial habenulo-interpeduncular (MHb-IPN) pathway plays an integral role in the aversive actions of nicotine and symptomology associated with nicotine withdrawal (Herkenham and Nauta, 1979; Salas et al., 2009; Fowler et al., 2011; Frahm et al., 2011; Fowler and Kenny, 2014; Antolin-Fontes et al., 2015; Pang et al., 2016; Sherafat et al., 2020). This pathway densely expresses several nicotinic subunits, including $\alpha 3$, $\alpha 4, \alpha 5, \beta 2$ and $\beta 4$ (Clarke et al., 1985, 1986; Mulle et al., 1991; Grady et al., 2009; Salas et al., 2009; Feduccia et al., 2012; Hendrickson et al., 2013). Of significance, in humans, polymorphisms of the CHRNB4-CHRNA3-CHRNA5 gene cluster encoding for the $\alpha 3, \beta 4$, and $\alpha 5 \mathrm{nAChR}$ subunits have been repeatedly associated with nicotine dependence (Freathy et al., 2009; Saccone et al., 2009; Zhang et al., 2010; Freathy et al., 2011). These nAChR subunits in the MHb-IPN pathway appear to modulate the aversive properties of nicotine, particularly at higher doses. Both constitutive knockout of the $\alpha 5 \mathrm{nAChR}$ subunit in mice and MHb-specific knockdown of the a $5 \mathrm{nAChR}$ gene in the rat leads to an increase in nicotine self-administration at higher doses (Fowler et al., 2011, 2013). In the knockout mice, $\alpha 5 \mathrm{nAChR}$ subunit re-expression in the $\mathrm{MHb}$ was sufficient to restore the behavioral phenotype, with no significant difference found in nicotine self-administration behavior compared to wildtype controls (Fowler et al., 2011). In contrast, mice with overexpression of the $\beta 4 \mathrm{nAChR}$ gene exhibit a strong aversion to nicotine (Frahm et al., 2011). Finally, knockdown of the $\alpha 3 \mathrm{nAChR}$ subunit in the $\mathrm{MHb}$ or IPN increases nicotine intake at higher doses, a behavioral effect also found with the infusion of the a3 34 antagonist, a-conotoxin AuIB, into the IPN (Elayouby et al., 2021). Interestingly, the $\alpha 3 \beta 4$-containing nAChR has further been implicated in the physical signs of nicotine withdrawal (Jackson et al., 2013), which may involve altered GABAergic signaling in the IPN (Zhao-Shea et al., 2013). Finally, inhibition of these IPN GABAergic projections to the laterodorsal tegmentum has been shown to attenuate nicotine-conditioned place aversion (Wolfman et al., 2018). Therefore, given the multiple actions of nicotine on varying brain circuits, the downstream effects on gene expression can 
lead to a persistent impact on processes underlying nicotine use and abuse.

\section{NICOTINIC SIGNALING AND GENE EXPRESSION ALONG THE DRUG USE TRAJECTORY}

Long-term changes in gene expression are thought to lead to behavioral habits and underlying processes that characterize the state of drug dependence, which can occur following consumption of nicotine-containing products including tobacco cigarettes and e-cigarettes/vapes (Figure 1). While the effects of nicotine on gene expression may be directly attributed to activation of nAChRs on the postsynaptic membrane, it is important to recognize that $\mathrm{nAChRs}$ can act as heteroreceptors to regulate the release of many neurotransmitters, in addition to acetylcholine, from the presynaptic terminal. Thus, nicotine's effects on gene expression may be both directly on the nAChRexpressing cell, as well as indirectly with the involvement of multiple neurotransmitter systems. In the following paragraphs, we discuss evidence supporting interaction among nicotinic signaling, gene expression, and behavior, which may underlie various facets of drug use and abuse. These findings are further summarized in Table 1.

\section{Acute Nicotine Exposure}

Experimenter-administered nicotine allows for precise dosing when one is interested in examining acute drug effects across experimental conditions, thereby elucidating findings particularly relevant to initial drug use. Acute nicotine exposure has been shown to increase the mRNA and protein expression of $c$-fos, an immediate early gene and marker of cellular activation, in various regions throughout the brain. For instance, nicotinemediated increases in $c$-fos mRNA and/or protein expression have been documented in the VTA, MHb, and IPN, particularly at higher doses (Cole et al., 1989; Ren and Sagar, 1992; Sharp et al., 1993; Fowler et al., 2011; Baur et al., 2018). Since the VTA, MHb, and IPN have important roles in nicotine reinforcement and aversion, activation of these brain regions likely contributes to the drive to further consume the drug (Picciotto et al., 1998; Tapper et al., 2004; Changeux, 2010; Fowler et al., 2011; Frahm et al., 2011; Fowler et al., 2013). These activational effects are generally attributed to the direct actions of nicotine on the nAChRs, since pretreatment with the general nAChR antagonist, mecamylamine, can prevent such c-fos expression (Sharp et al., 1993). Given the regulatory regions in the $c$-fos gene, it is likely that the increased $\mathrm{Ca}^{2+}$ influx induced with $\mathrm{nAChR}$ opening leads to activation of second messenger systems, such as MAP- and CAM-kinases, thereby inducing the $c$-fos gene transcription (Kovács, 1998). In addition to reinforcement and aversion-related brain regions, nicotine-induced $c$-fos mRNA and/or protein expression has been evidenced in the hippocampus, substantia nigra, nucleus of the tractus solitarius, striatum, amygdala, and cortex, all of which appear to play a role in different aspects of drug dependence (Sharp et al., 1993; Koob and Volkow, 2010; Zhao-Shea et al., 2013; Tuesta et al., 2017; Dehkordi et al.,
2018). Therefore, the extensive changes in $c$-fos gene expression provide insight into the broad actions of nicotine on neural signaling. Interestingly, repeated dosing appears to elicit nAChR desensitization in these actions, as a reduction in the expression of $c$-fos mRNA is found in the hippocampus and cortex after a second nicotine dose (Sharp et al., 1993); desensitization of nAChRs has been proposed to contribute to conditioned drug reward through salience of environmental cues associated with nicotine consumption (Klink et al., 2001). Moreover, while the c-fos protein has been shown to induce activation of multiple gene targets, one should note that: (1) expression may not change in cells exhibiting a net inhibitory state; (2) the protein may form a dimer with JunB to induce an inhibitory effect; and (3) the level of c-fos protein induced may not reach a sufficient threshold level to drive the transcriptional activity of all the target genes within a cell (Sheng and Greenberg, 1990; Kovács, 1998). Furthermore, while examining the acute actions of nicotine may provide some initial insights, chronic exposure conditions provide arguably more translational relevance for the changes in gene expression that likely occur in human smokers, which could alter neural function to potentially propagate the dependence state across time.

\section{Chronic Nicotine Exposure}

Longer-term exposure to nicotine has been demonstrated to exert changes in gene expression across cell types and brain regions. In recently abstinent smokers, increased $\beta 2$-containing nAChRs are found in the cortex and striatum (Staley et al., 2006). Data derived from animal models provides further evidence of increased nicotine-mediated expression for a subset of nAChR subunits in a region-specific manner (Marks et al., 1987, 1992; Adriani et al., 2003; Staley et al., 2006; Nashmi et al., 2007). For instance, chronic nicotine exposure leads to upregulation of the $\alpha 6$ and $\beta 3 \mathrm{nAChR}$ subunits in the substantia nigra pars compacta (Visanji et al., 2006) and $\alpha 7 \mathrm{nAChR}$ subunits in the substantia nigra and VTA (Ryan and Loiacono, 2001). Also, the effects on $\mathrm{nAChR}$ expression involve differences in the assembly of the subunits to generate functional receptors at the membrane. Specifically, the $\alpha 4$ and $\beta 2 \mathrm{nAChR}$ subunits can combine to form different isoforms with either two $\alpha 4$ subunits $\left(\alpha 4_{2} \beta 2_{3}\right)$ or three $\alpha 4$ subunits $\left(\alpha 4_{3} \beta 2_{2}\right)$. Chronic exposure to nicotine preferentially upregulates $\alpha 4_{2} \beta 2_{3} \mathrm{nAChRs}$ in the cortex, but not the thalamus (Fasoli et al., 2016), thereby demonstrating increased expression of the higher sensitivity $\alpha 4_{2} \beta 2_{3}$ isoform following nicotine exposure in a region-specific manner. Additionally, the $\alpha 4$ and $\beta 2$ subunits can also combine with the $\alpha 5$ subunit to form the $\alpha 4_{2} \beta 2_{2} \alpha 5$ subtype, but the expression of this subtype does not change with nicotine exposure (Moretti et al., 2018). Further specificity is found for cell type specific patterns. Nicotine-mediated upregulation of $\alpha 4$-containing nAChRs occurs in the VTA and substantia nigra, but the increased expression is specific to GABAergic, not dopaminergic, neurons (Nashmi et al., 2007). With regard to the MHb-IPN circuit, $\alpha 5 \mathrm{nAChR}$ subunit expressing neurons in the IPN upregulate expression of the Nos1 and Sst genes following repeated nicotine administration, leading to increased nitric oxide and somatostatin neurotransmitter release, respectively 
TABLE 1 | Examples of gene expression changes with nicotine exposure.

\begin{tabular}{|c|c|c|c|c|c|}
\hline $\begin{array}{l}\text { Nicotine } \\
\text { exposure }\end{array}$ & $\begin{array}{l}\text { Direction of } \\
\text { change }\end{array}$ & Brain region(s) & Genes & Functional implications & Citation(s) \\
\hline \multirow[t]{9}{*}{ Acute } & \multirow[t]{9}{*}{ Increase } & $\begin{array}{l}\text { AMG, Cortex, Hipp, } \\
\text { IPN, MHb, NTS, } \\
\text { SN, STR, VTA }\end{array}$ & Fos & $\begin{array}{l}\text { Fos proto-oncogene; involved in neuronal } \\
\text { activation; activation of these brain regions may } \\
\text { be sufficient to alter nicotine intake. }\end{array}$ & $\begin{array}{l}\text { Cole et al. (1989), Ren and } \\
\text { Sagar (1992), Sharp et al. } \\
\text { (1993), Picciotto et al. (1998), } \\
\text { Tapper et al. (2004), Changeux } \\
\text { (2010), Koob and Volkow } \\
\text { (2010), Fowler et al. (2011, } \\
\text { 2013), Frahm et al. (2011), } \\
\text { Mineur et al. (2011), Picciotto } \\
\text { and Mineur (2013), Zhao-Shea } \\
\text { et al. (2013), Tuesta et al. } \\
\text { (2017), Baur et al. (2018) and } \\
\text { Dehkordi et al. (2018) }\end{array}$ \\
\hline & & Forebrain & Arc & $\begin{array}{l}\text { Activity-regulated cytoskeleton-associated } \\
\text { protein; involved in neuronal activation and } \\
\text { plasticity; may increase reinforcing effects of } \\
\text { nicotine. }\end{array}$ & $\begin{array}{l}\text { Schochet et al. (2005) and } \\
\text { Goriounova and Mansvelder } \\
\text { (2012) }\end{array}$ \\
\hline & & PFC & $D d n$ & $\begin{array}{l}\text { Dendrin; involved in learning and memory; } \\
\text { adolescent-specific changes following acute } \\
\text { nicotine. }\end{array}$ & $\begin{array}{l}\text { Schochet et al. (2008), Doura } \\
\text { et al. (2010) and Ji et al. (2019) }\end{array}$ \\
\hline & & VTA & Gria1 & $\begin{array}{l}\text { Glutamate ionotropic receptor AMPA subunit; } \\
\text { involved in glutamatergic cell signaling; may } \\
\text { enhance reinforcing response to nicotine. }\end{array}$ & $\begin{array}{l}\text { Picciotto et al. (1998), Ferrari } \\
\text { et al. (2002), Pons et al. (2008) } \\
\text { and Yan et al. (2019) }\end{array}$ \\
\hline & & $\begin{array}{l}\text { In vitro } \\
\text { (neuroblastoma cell }\end{array}$ & $\begin{array}{l}\text { IL1B, IL6, } \\
\text { CRELD2, }\end{array}$ & $\begin{array}{l}\text { Interleukin } 1 \text { beta and Interleukin; involved in the } \\
\text { inflammatory response. }\end{array}$ & $\begin{array}{l}\text { Ortiz et al. (2005), Hosur et al. } \\
\text { (2009) and Bai et al. (2019) }\end{array}$ \\
\hline & & line) & $\begin{array}{l}\text { PDIA6, } \\
\text { HERPUD1 }\end{array}$ & $\begin{array}{l}\text { Cysteine, rich with EGF like domains 2; may be } \\
\text { involved in the transport of nAChRs. }\end{array}$ & \\
\hline & & & & $\begin{array}{l}\text { Protein disulfide isomerase family A member } 6 \text {; } \\
\text { involved in cell proliferation. }\end{array}$ & \\
\hline & & & & Homocysteine inducible ER protein with & \\
\hline & & & & $\begin{array}{l}\text { ubiquitin-like domain 1; involved in stress } \\
\text { response in the endoplasmic reticulum. }\end{array}$ & \\
\hline
\end{tabular}

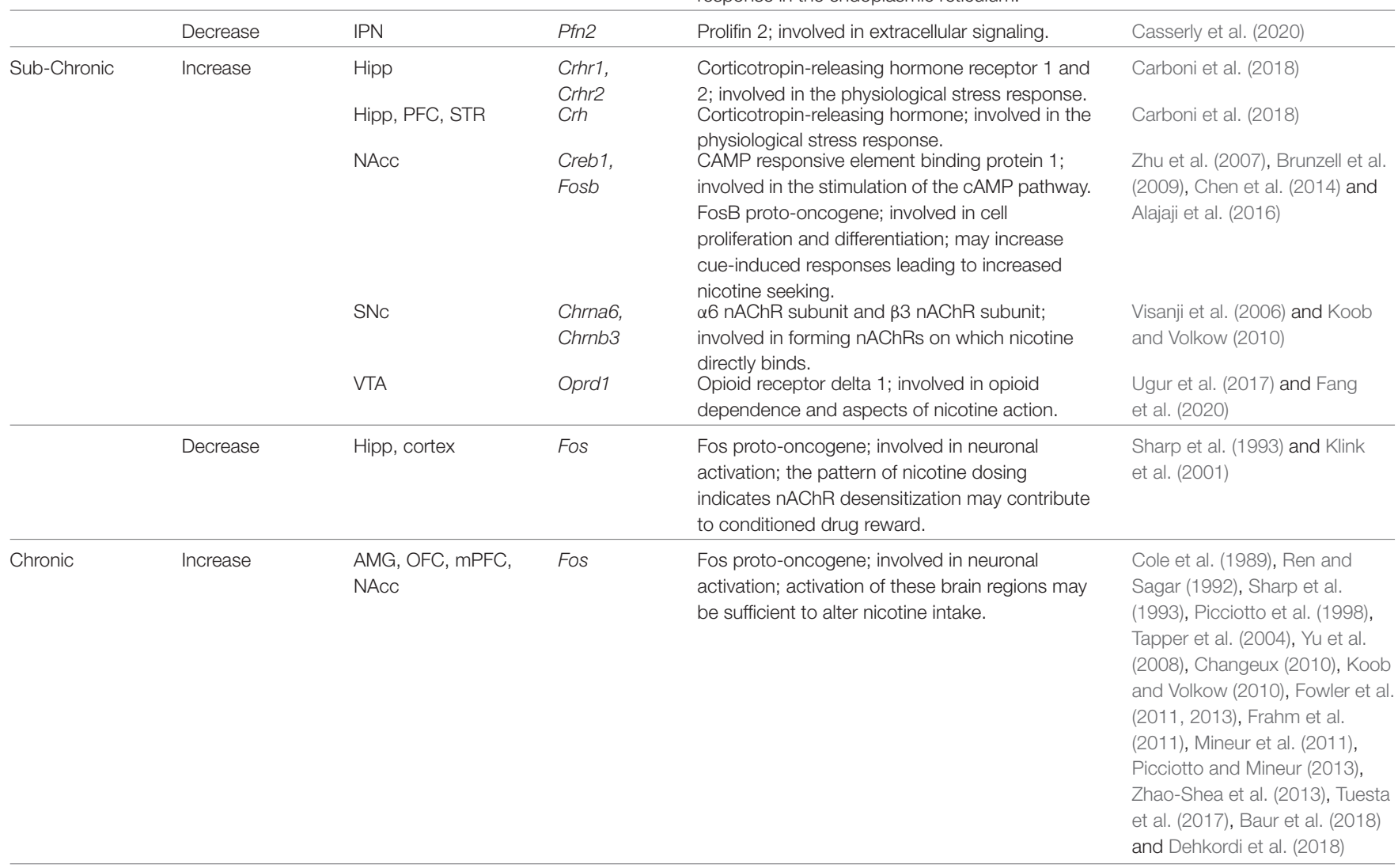

(Continued) 
TABLE 1 | Continued

\begin{tabular}{|c|c|c|c|c|c|}
\hline $\begin{array}{l}\text { Nicotine } \\
\text { exposure }\end{array}$ & $\begin{array}{l}\text { Direction of } \\
\text { change }\end{array}$ & Brain region(s) & Genes & Functional implications & Citation(s) \\
\hline & & $\begin{array}{l}\text { Cortex, SN, VTA } \\
\text { (GABAergic } \\
\text { neurons) }\end{array}$ & Chrna4 & $\begin{array}{l}\alpha 4 \text { nAChR subunit; forms subtypes of } \mathrm{nAChRs} \\
\text { on which nicotine directly binds. }\end{array}$ & $\begin{array}{l}\text { Picciotto (1998), Ferrari et al. } \\
\text { (2002), Rice and Cragg (2004), } \\
\text { Kenny and Markou (2006), } \\
\text { Fasoli et al. (2016), Correa et al. } \\
\text { (2019), Mahler et al. (2019) and } \\
\text { Yan et al. (2019) }\end{array}$ \\
\hline & & $\begin{array}{l}\text { Cortex, IPN } \\
\text { (male-specific), IPN } \\
\text { (female-specific }\end{array}$ & Chrb2 & $\begin{array}{l}\beta 2 \mathrm{nAChR} \text { subunit; forms subtypes of } \mathrm{nAChRs} \\
\text { on which nicotine directly binds. }\end{array}$ & $\begin{array}{l}\text { Staley et al. (2006), Fasoli et al. } \\
\text { (2016) and Correa et al. (2019) }\end{array}$ \\
\hline
\end{tabular}

during nicotine

withdrawal), STR

Choroid plexus

Mir204, Ttr

$\begin{array}{ll}\text { Hipp } & \text { Nrg3, } \\ \text { Creb1 }\end{array}$

Hypothalamus

IPN

Npy, Agrp

Nos1, Sst

IPN (male-specific) SN, VTA

IPN (female-specific)

NAcc

PFC

SN

VTA
Chrna7

Chrna5

Nox2, $/ 11 b$,

Tnf

Mir199a,

Mir214,

Bdnf

Chrna6,

Chrnb3

Chrna5,

Chrna6,

Chrnb2,

Dnm1, Ghr,

мap
MicroRNA 204; involved in regulating non-coding RNAs, anti-apoptotic signaling, linked to Schizophrenia in GWAS study. Transthyretin; involved in thyroid hormone and retinol transport, $A \beta$ clearance in brain, linked to Alzheimer's disease and Schizophrenia in GWAS study.

Neuregulin 3; involved in intracellular signaling, nicotine-related anxiety symptomology CAMP responsive element binding protein; involved in the stimulation of the CAMP pathway, nicotine-mediated responses, and withdrawal symptoms.

Neuropeptide $Y$ and Agouti-related neuropeptide; involved in food intake and weight regulation.

Nitric oxide synthase 1 and Somatostatin; upregulation in $\alpha 5$ containing neurons contributes to signaling for nicotine withdrawal and aversion.

$\alpha 7$ nAChR subunit; forms homomeric subtype of $n A C h R s$ on which nicotine directly binds; involved in reward-related behaviors. $\alpha 5 \mathrm{nAChR}$ subunit; forms subtypes of nAChRs on which nicotine directly binds; contributes to nicotine withdrawal and aversion phenotypes. NADPH oxidase 2; involved in microglia morphology.

Interleukin 1 beta; involved in the inflammatory response.

Tumor necrosis factor; involved in cell proliferation.

microRNA 199a and 214; implicated in cell proliferation with cancer.

Brain-derived neurotrophic factor; involved in nerve growth, learning and memory, and cellular signaling.

$\alpha 6$ nAChR subunit and $\beta 3$ nAChR subunit;

forms subtypes of $n A C h R s$ on which nicotine directly binds; correlated with increased nicotine self-administration.

$\alpha 5$ nAChR subunit, $\alpha 6$ nAChR subunit; $\beta 2 \mathrm{nAChR}$ subunit; forms subtypes of nAChRs on which nicotine directly binds; may enhance reinforcing response to nicotine.

Dynamin; involved in cellular membranes Growth hormone receptor; involved in cellular growth.

Mitogen-Activated Protein; involved in cell proliferation.
Serot et al. (1997), Wan et al. (2006), Turner et al. (2014b), Cammaerts et al. (2015) and Lallai et al. (2019)

Turner et al. (2014a), Fisher et al. (2017) and Zhou et al. (2018)

Huang et al. (2011)

Herkenham and Nauta (1979), Salas et al. (2009), Fowler et al. (2011), Frahm et al. (2011),

Fowler and Kenny (2014), Antolin-Fontes et al. (2015), Pang et al. (2016), Ables et al. (2017) and Sherafat et al. (2020) Panagis et al. (2000), Ryan and Loiacono (2001) and Visanji et al. (2006) Ables et al. (2017) and Correa et al. (2019)

Adeluyi et al. (2019) and Namba et al. (2020)

Dhungel et al. (2018), Pittenger et al. (2018), Cole et al. (2020) and Tornesello et al. (2020)

Visanji et al. (2006), Quik et al. (2011) and Renda and Nashmi (2014)

Visanji et al. (2006), Doura et al. (2010), Berrendero et al. (2012) and Henderson et al. (2017) 
TABLE 1 | Continued

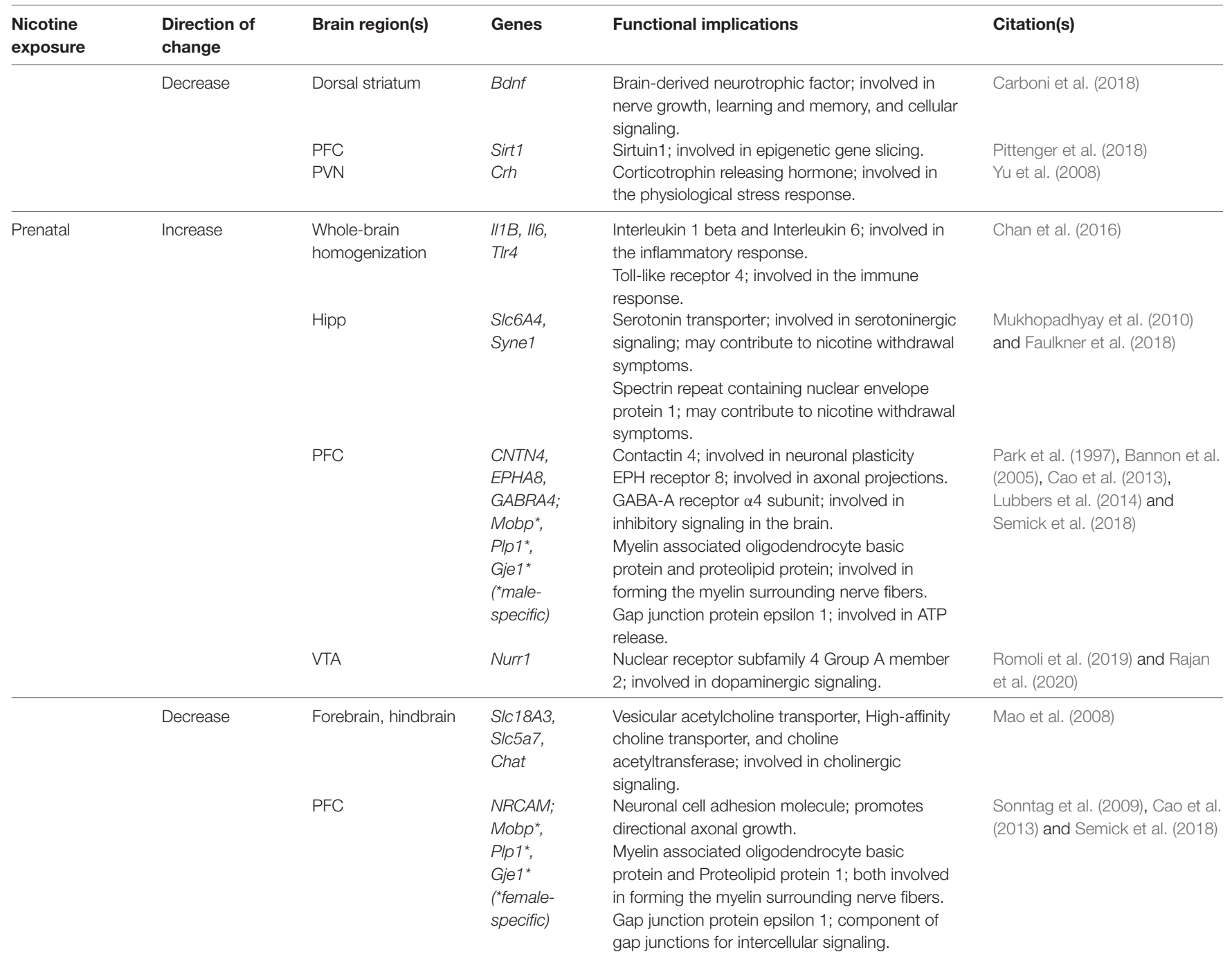

Acute, one injection; Sub-chronic, <10 injections/exposures; Chronic, >10 injections/exposures; AMG, amygdala; Hipp, hippocampus; IPN, interpeduncular nucleus; MHb, medial habenula; MPFC, medial prefrontal cortex; NAcc, nucleus accumbens; NTS, nucleus of the tractus solitarius; OFC, orbitofrontal cortex; PFC, prefrontal cortex; PVN, paraventricular nucleus; SN, substantia nigra; SNc, substantia nigra pars compacta; STR, striatum; VTA, ventral tegmental area.

(Ables et al., 2017). Since blocking nitric oxide signaling also reduces nicotine preference (Ables et al., 2017), this further demonstrates a potential feedback mechanism for bidirectional effects between nicotine-seeking behavior and gene expression. Additionally, somatostatin has been shown to inhibit glutamate release in the IPN (Zhao-Shea et al., 2013), suggesting that upregulation of somatostatin could further serve to inhibit the activity of the aversion-related MHb-IPN circuit. Interestingly, sex differences have also been found in the IPN expression of acetylcholine and $\mathrm{nAChRs}$ following nicotine treatment. Specifically, females exhibit a greater increase in acetylcholine and $\alpha 5 \mathrm{nAChR}$ subunit mRNA levels, whereas males show an increase $\alpha 7$ and $\alpha 2 \mathrm{nAChR}$ subunit transcripts, in the IPN (Correa et al., 2019). It is also important to note that changes in nAChR subunit mRNA are not always associated with the level of protein expression at the membrane, and inversely, changes in $\mathrm{nAChR}$ membrane expression are not always a product of changes in $\mathrm{nAChR}$ gene expression. Indeed, membrane nAChR upregulation can be modulated by post-translational modifications or trafficking. For example, nicotine has been shown to upregulate receptors containing the $\alpha 4$ and $\beta 2 \mathrm{nAChR}$ subunits via several mechanisms, including phosphorylation and chaperoning in the endoplasmic reticulum, which could lead to increased receptor insertion at the cell surface (Rothhut et al., 1996; Lester et al., 2009; Wecker et al., 2010; Srinivasan et al., 2011). Since $\alpha 4$ and $\beta 2 \mathrm{nAChR}$ subunits in the VTA-NAcc circuit are necessary for nicotine reinforcement, the net effect of an upregulation in $\alpha 4 \beta 2$-containing nAChRs could be enhanced reinforcing effects of the drug at various doses (Picciotto et al., 1998; Tapper et al., 2004; Changeux, 2010).

Next, chronic nicotine exposure may lead to the modulation of membrane nAChRs through effects on other genes expressed in the cell. In a recent study, an innovative proteomics approach was taken to immunoprecipitate protein-protein interactions 
of $\beta 2$-containing $\mathrm{nAChRs}$ and subsequently characterize the associated proteins (McClure-Begley et al., 2016). It was found that chronic nicotine exposure increases the expression of specific nAChR interacting proteins, including $\mathrm{Na} / \mathrm{K}$ ATPases, syntaxins, SNAP25, and synaptotagmin, in the cortex of both mice and human smokers (McClure-Begley et al., 2016), thereby revealing the impact of nicotine on the expression of intracellular factors involved in $\mathrm{AAChR}$ regulation. In addition to nicotine, other constituents in tobacco and e-cigarette products may independently or synergistically act with nicotine to alter neuronal function. For instance, menthol is a common additive found both in tobacco cigarettes and e-cigarette vape solutions. When menthol and nicotine are co-administered, a significant upregulation of $\alpha 4 \alpha 6 \beta 2 \mathrm{nAChRs}$ is found in the VTA, substantia nigra, and hypothalamus, as compared to nicotine alone (Henderson et al., 2017; Mulcahy et al., 2020), which is positively correlated with dopaminergic neuron excitability and increased drug reward (Henderson et al., 2017). Therefore, a bidirectional relationship is present between behavior and gene expression, in which drug consumption causes upregulation of nAChRs, which can subsequently affect neural responsiveness in brain regions that mediate aversion or reinforcement signaling that regulate later drug intake.

A variety of other genes have also been identified to be differentially regulated by nicotine exposure. In the VTA, increased mRNA expression of the delta-opioid receptor and GluA1 AMPA receptor are found with nicotine (Ferrari et al., 2002; Ugur et al., 2017; Fang et al., 2020); both of these receptors have been implicated in nicotine self-administration behavior (Kenny et al., 2009; Fowler et al., 2011; Berrendero et al., 2012). Further, decreased density of the metabotropic glutamate receptor 5 (mGluR5) has been documented in human smokers (Akkus et al., 2013). These findings were confirmed in rats following 250 days of nicotine exposure, in which decreased mGluR5 was found in the striatum, hippocampus, thalamus, and midbrain, and these changes in density were also associated with decreased exploratory behavior (Müller Herde et al., 2019). Abstinence following nicotine exposure restored mGluR5 expression (Müller Herde et al., 2019). However, another study examining nicotine-mediated changes in mGluR5 transcripts resulted in discrepant findings (Kane et al., 2005). Repeated nicotine injections have also been shown to induce expression of CREB in the NAcc, which appears to be essential for Pavlovian conditioning to nicotine-associated cues (Brunzell et al., 2009). Finally, nicotine can alter the expression of miRNAs in the brain, which may lead to subsequent effects on protein expression for multiple target genes. For instance, our recent study found that nicotine self-administration leads to an increase in mir204 and transthyretin in the choroid plexus of rats, both of which are released into the cerebrospinal fluid as circulating signaling factors (Cammaerts et al., 2015; Lallai et al., 2019; Sharma et al., 2019). Of note, both transthyretin and mir-204 have been implicated in regulating cell survival and may be involved in pathological states, such as Alzheimer's disease and/or Schizophrenia (Serot et al., 1997; Wan et al., 2006; Turner et al., 2014b; Cammaerts et al., 2015; Li et al., 2016). Moreover, in females, but not males, nicotine self-administration was also found to induce an upregulation of mir199a and mir214 in the PFC, leading to a downregulation in protein expression of the target mRNA SIRT1 (Pittenger et al., 2018). Therefore, nicotine appears to induce actions on multiple genes across brain regions in a sex-dependent manner.

\section{Nicotine Withdrawal and Relapse}

Nicotine withdrawal is characterized by several adverse symptoms in both human and rodent models, including increased anxiety and cognitive deficits (Damaj et al., 2003; West, 2006). Differential gene expression occurring during the withdrawal state may mediate symptomology. As noted above, the MHb-IPN circuit has been implicated in nicotine withdrawal. In the IPN, nicotine abstinence is associated with increased gene expression of the $\alpha 4, \alpha 5$, and $\beta 2 \mathrm{nAChR}$ subunits (Correa et al., 2019) and decreased expression of the $P f n 2$ gene (Casserly et al., 2020). Interestingly, knockdown of Pfn2 in the IPN, but not in the VTA, results in an increased anxiety-related phenotype (Casserly et al., 2020), supporting a role in withdrawal-induced anxiety. The hippocampus has also been implicated in regulating anxiety-associated behaviors. During nicotine withdrawal, an increase in neuregulin 3 appears to mediate the synaptic plasticity that underlies anxiety-associated symptomology (Turner et al., 2014a; Zhou et al., 2018). Further, in the ventral hippocampus, the transcription factor CREB contributes to anxiety-associated behaviors during the withdrawal state (Fisher et al., 2017). Abstinence from drugs of abuse also activates stress-related signaling that involves corticotropin-releasing factor (CRF) and the associated $\mathrm{CRF}_{1}$ and $\mathrm{CRF}_{2}$ receptors (George et al., 2007). Following chronic nicotine, CRF levels are upregulated in the VTA, striatum, PFC, and hippocampus ( Grieder et al., 2014; Zhao-Shea et al., 2015; Carboni et al., 2018), but downregulated in the paraventricular nucleus ( $Y u$ et al., 2008). Further, $\mathrm{CRF}_{1}$ and $\mathrm{CRF}_{2}$ receptors are found to be increased in the hippocampus (Carboni et al., 2018), and hippocampal CRF signaling has been implicated in anxietyassociated behaviors (Bertagna et al., 2021). Taken together, these findings demonstrate that a variety of gene expression changes during the withdrawal state may contribute to anxietyand/or stress-related behavioral effects.

Deficits in cognitive function are also found with nicotine withdrawal. For instance, mice treated chronically with both moderate and high doses of nicotine exhibit impaired cognitive flexibility during a set-shifting task, and these deficits were associated with increased $B d n f$ gene expression in the medial PFC but decreased $B d n f$ in the dorsal striatum (Cole et al., 2020). Increased expression of nAChRs and CREB in the dorsal hippocampus has also been associated with learning deficits during nicotine withdrawal (Gould et al., 2014; Fisher et al., 2017), which also involves changes in other genes associated with long term potentiation for new contextual learning events, but not an expression of previously acquired contextual memory (Portugal and Gould, 2009). Finally, it is important to recognize the emerging importance of glial signaling in brain function. During nicotine withdrawal, proinflammatory effects have been associated with anxiogenic behaviors (Adeluyi et al., 2019). In the NAcc, nicotine withdrawal induces a change in microglial 
morphology, decreases astrocyte GFAP expression, and increases expression of Nox2, tumor necrosis factor- $\alpha$, and interleukin- $1 \beta$ (Adeluyi et al., 2019; Namba et al., 2020). Thus, gene expression changes during abstinence from nicotine may contribute to various behavioral effects associated with the withdrawal state.

High relapse rates are often found when one attempts to quit the tobacco/nicotine smoking habit, and thus, ascertaining a better understanding of the neurobiological components modulating drug relapse may reveal new targets for therapeutic intervention. Drug relapse can involve the persistent memories of nicotine reward, aversive effects of withdrawal, and nicotineassociated conditioned stimuli (Herd et al., 2009; Pickens et al., 2011). Increased nicotine-seeking behavior after a prolonged period of abstinence is correlated with higher levels of c-fos protein expression in the amygdala, orbitofrontal cortex, medial prefrontal cortex, and NAcc (Funk et al., 2016). Further, glutamatergic plasticity in the NAcc, including alterations in the expression of the AMPA receptor and cholinergic interneuron function, has been shown to mediate cue-induced reinstatement (Vieyra-Reyes et al., 2008; Gipson et al., 2013; LeyrerJackson et al., 2020). Also, neuronal subpopulations within the basolateral amygdala appear to encode reward-associated memories, as selective inhibition of these neurons prevents nicotine seeking in both the conditioned place preference and incubation of craving paradigms (Xue et al., 2017). These findings support the notion that changes in gene expression may contribute to the likelihood of relapse-associated behaviors during abstinence.

Finally, weight gain following cessation may also contribute to high relapse rates, and studies examining the intersection of nicotine and feeding have found that nicotine induces c-fos protein expression in pro-opiomelanocortin and neuropeptide $\mathrm{Y}$ neurons of the arcuate nucleus, a brain region shown to mediate satiety (Fornari et al., 2007; Huang et al., 2011; Mineur et al., 2011; Picciotto and Mineur, 2013). Withdrawal from nicotine increases body weight, neuropeptide $\mathrm{Y}$, and agouti-related protein expression in the hypothalamus, and these proteins have been implicated in regulating appetite and metabolism (Fornari et al., 2007). Together, these studies highlight a role for nicotinerelated gene expression changes in body weight regulation, which may contribute to the propensity for drug use and relapse.

\section{FURTHER CONSIDERATIONS FOR NICOTINE-MEDIATED CHANGES IN GENE EXPRESSION}

Nicotine's actions across the drug use trajectory may be modulated by several factors, in addition to $\mathrm{nAChR}$ receptor subtype expression and intracellular signaling cascades. In the following sections, we discuss additional considerations that can mediate nicotine's actions at the various stages of drug use. First, we highlight the effects of nicotine across early developmental stages, and then we discuss the role of endogenous allosteric modulators that can play a key role in nicotine's ability to induce a $\mathrm{nAChR}$ conformational change and/or modulate membrane expression (Morishita et al., 2010). Thereafter, we examine emerging evidence correlating changes in the epigenetic landscape with nicotine use.

\section{Developmental Effects of Nicotine on Gene Expression}

While the above studies have focused on changes in gene expression occurring in the adult, it is important to consider the impact of nicotine during earlier developmental stages when the brain is highly susceptible to environmental influences. Maternal smoking has been associated with adverse consequences for the fetus, which includes altered development of cholinergic systems and low birth weight (Ernst et al., 2001). Importantly, the potential negative impact on the fetus is not restricted to high levels of smoking behavior, as second-hand smoke exposure has also been correlated with impaired cognitive development (Rauh et al., 2004). Studies of post-mortem tissue document altered gene expression in the prefrontal cortex of fetuses from smoking mothers, including increased expression of genes involved in neurodevelopment (CNTN4, EPHA8, and GABRA4) and decreased expression of genes involved in cell adhesion (NRCAM) and calcium signaling (KCNN2; Semick et al., 2018). However, for the most part, long-term behavioral outcomes in humans remain inconclusive due to potentially confounding factors, such as differential environmental, nutritional, and genetic influences among subjects. Thus, rodent models are essential to better elucidate the effects of developmental nicotine exposure on gene expression and behavior. A study from Mao et al. (2008) confirmed nicotineinduced dysregulation within the cholinergic system, in which early prenatal nicotine exposure led to decreased expression of choline acetyltransferase, vesicular acetylcholine transporter, and choline transporter in the forebrain and hindbrain of rats (Mao et al., 2008). Also, sidestream cigarette smoke exposure in dams, a model of second-hand exposure, resulted in dysregulation of numerous genes in the mouse hippocampus, including upregulated serotonin transporter gene Slc6a4 and synaptic nuclear envelope gene Syne1 (Mukhopadhyay et al., 2010). Importantly, sex-dependent changes have also been found with in utero nicotine exposure. The axon myelinationassociated genes, Mobp, Plp1, and Gje1, were significantly upregulated in male, but downregulated in female, rat PFC following chronic gestational nicotine exposure (Cao et al., 2013). Maternal cigarette smoke exposure also resulted in increased expression of inflammatory signaling factors, including IL- $1 \beta$, IL-6, and toll-like receptor 4 in adult male mice, although females were not examined in this study (Chan et al., 2016). Consistent with these findings, the impact of nicotine on immune signaling molecules has been further demonstrated with in vitro studies. In an $\alpha 4$ and $\beta 2$ expressing neuroblastoma cell line, nicotine application downregulated gene expression of the inflammatory proteins IL- $1 \beta$ and IL- 6 and increased expression of the endoplasmic reticulum proteins CRELD2, PDIA6, and HERPUD1 (Hosur et al., 2009). Interestingly, knockout of the CRELD2 protein increased $\alpha 4$ and $\beta 2 \mathrm{nAChR}$ subunit expression, suggesting a bidirectional effect on gene regulation in this in vitro system (Hosur et al., 2009). Finally, a recent study has demonstrated that prenatal nicotine exposure increases the 
expression of Nurr1 in the VTA, leading to a greater number of dopaminergic neurons and enhanced nicotine preference in adulthood (Romoli et al., 2019).

In addition to in utero developmental exposure, adolescence is a sensitive period for consequential effects of nicotine on the brain, which also involves sex-specific outcomes (Cross et al., 2017). Following nicotine exposure in adolescence, an upregulation in the expression of the nAChR subunits $\alpha 5, \alpha 6$, and $\beta 2$, as well as genes associated with synaptic plasticity (Dnm1), neuron density (Ghr), and dendrite elongation (Map), is found in the VTA in adulthood (Adriani et al., 2003; Doura et al., 2010; Locker et al., 2016). Interestingly, many of these changes in gene expression are specific to nicotine exposure in adolescence, but not adulthood (Doura et al., 2010). Other brain regions, including the hippocampus, NAcc, and PFC, exhibit nicotine-mediated changes in gene expression following adolescent exposure, with differential effects based on the specific stage of adolescence (Polesskaya et al., 2007). Adolescent nicotine exposure also induces an upregulation in DeltaFosB in the NAcc (Alajaji et al., 2016), a transcription factor associated with neural changes underlying substance abuse (Nestler et al., 2001). Additional genes identified are involved in synaptic plasticity, including Arc and Dendrin (Schochet et al., 2005, 2008), suggesting that such long-term changes with adolescent nicotine exposure can mediate a variety of effects in adulthood underlying various affective, cognitive, and drug use behaviors (Goriounova and Mansvelder, 2012; Locker et al., 2016; Alajaji et al., 2016; Pushkin et al., 2019; Dukes et al., 2020). These studies demonstrate that nicotine consumption during adolescence can induce long-term changes in brain circuitry persisting into adulthood.

\section{Endogenous Modulators of Nicotinic Receptors}

Recently, endogenous allosteric modulators have been found to associate with nAChRs to alter the ability of ligands, including nicotine or acetylcholine, to induce an open conformational state of the receptor (Delbart et al., 2018). By modulating nAChR activity at the membrane, the consequential significance of the allosteric modulator on gene expression can be both shortor long-lived via modulation of $\mathrm{Ca}^{2+}$ influx for subsequent second messenger signaling. In addition to effects on membranelocalized nAChRs, endogenous modulators may also affect the trafficking of $\mathrm{nAChR}$ subunits to the membrane via association in the endoplasmic reticulum (Nichols et al., 2014; Miwa et al., 2019). Moreover, different endogenous modulators have been found to preferentially interact with specific nAChR subtypes and to be expressed in a region- and cell-specific manner, allowing for a potential high specificity in their effects (George et al., 2017; Miwa et al., 2019; Anderson et al., 2020). For instance, RIC-3, the resistance inhibitors of cholinesterase 3, has been shown to increase $\alpha 4$ and $\beta 2 \mathrm{nAChR}$ subunit protein expression, but not the assembly of these subunits into the $\alpha 4 \beta 2 \mathrm{nAChR}$ subtype (Dau et al., 2013). Whereas initial studies suggested that RIC-3 does alter assembly and cell surface trafficking of $\alpha 7 \mathrm{nAChRs}$, but not $\alpha 7$ protein expression, it was subsequently demonstrated that RIC- 3 can affect $\alpha 7$ nAChR expression but in a ratio-dependent manner (Wang et al., 2009; Dau et al., 2013; Ben-David et al., 2016). Specifically, RIC-3 decreases a7 nAChR expression, but only at low ratios of RIC-3 to a7 nAChR subunits (Wang et al., 2009; Ben-David et al., 2016). In addition to the independent actions of allosteric modulators, two different allosteric modulators may work together to exert effects on nAChRs. For example, NACHO is a small, multi-pass transmembrane protein enriched in the neuronal endoplasmic reticulum acts as a chaperone to mediate the assembly and surface expression of $\alpha 7 \mathrm{nAChR}$ subunits (Matta et al., 2017). When localized together, RIC-3 can interact with NACHO to differentially regulate the expression of the $\alpha 7 \mathrm{nAChR}$ subunit (Matta et al., 2017).

Prototoxins are another class of allosteric modulators, which are classified into the lymphocyte antigen-6 (Ly-6)/urokinase plasmogenic activating receptor (u-PAR) superfamily. Similar to RIC-3 and NACHO, prototoxins can associate with and differentially modulate nAChR expression and function through interactions in the endoplasmic reticulum, cytoplasm, and membrane surface (Wu et al., 2015). The identified protoxins include lynx1, lynx2, and lypd6, which can associate with $\mathrm{nAChRs}$ by anchoring adjacent to the receptor on the membrane via a GPI link (Dessaud et al., 2006; Holford et al., 2009; Tekinay et al., 2009). Lynx proteins act as a "molecular brake pad" of the cholinergic system, negatively modulating the nAChR to reduce its activity in the presence of an agonist (Kobayashi et al., 2014). Association of lynx proteins with nAChRs decreases nicotineand acetylcholine-induced currents and increases desensitization (Miwa et al., 2006). Prototoxins can modulate cholinergic activity in a biologically applicable, spatially specific, and nAChR subtype-specific manner. For example, lynx1 has been shown to interact with the extracellular subunit interface of the nAChR, thereby altering receptor stoichiometry, nAChR assembly, and cell surface expression levels, leading to altered ligand-mediated cellular currents (Nichols et al., 2014). Lynxl can alter the function of $\alpha 6 \beta 2-, \alpha 4 \beta 2-, \alpha 3 \beta 4-$ and $\alpha 7$-containing nAChRs, as demonstrated in cell culture systems (Miwa et al., 2006; George et al., 2017). Lynx1 is highly expressed in brain regions implicated in nicotine dependence with localization in glutamatergic, GABAergic, and dopaminergic neurons (Sheffield et al., 2000; Demars and Morishita, 2014; Thomsen et al., 2014). Moreover, in dopaminergic neurons of the substantia nigra pars compacta, deletion of lynx1 reduces the function of the $\alpha 6$-containing nAChRs (Parker et al., 2017), indicating lynx1 modulation of $\alpha 6$-containing $\mathrm{nAChRs}$ occurs in these cellular populations. In contrast, lynx 2 has been shown to interact with $\alpha 4 \beta 2 \mathrm{nAChRs}$, to modulate nicotine's effects on glutamatergic signaling in the prefrontal cortex, and to mitigate anxiety-related behaviors (Dessaud et al., 2006; Tekinay et al., 2009; Demars and Morishita, 2014; Wu et al., 2015). Thus, allosteric modulators can act in conjunction with nicotine (or acetylcholine) to modulate protein expression in a cell type- and brain region-specific manner, but further studies in vivo will be necessary to more clearly delineate the relative importance of this interaction on subsequent behavior related to nicotine dependence. 


\section{Epigenetic Regulation}

Epigenetic modifications can serve to increase or decrease gene promotor accessibility for transcriptional activation. Interestingly, increased methylation in the promoter region of the monoamine oxidase A gene, the enzyme that metabolizes serotonin and norepinephrine, has been linked with increased vulnerability for nicotine dependence in women (Philibert et al., 2008), and differences in DNA methylation can serve as a predictor of smoking behavior in humans (Corley et al., 2019). An elegant study in mice demonstrated that nicotine increases expression of the Ash21/Mef2c complex during cortical development, which subsequently leads to changes in histone methylation in the promoter region of glutamatergic synaptic genes and representative changes in dendritic spine number and branching (Jung et al., 2016). In rats, chronic nicotine exposure has also been associated with a decrease in methylation of several genes in the medial prefrontal cortex, orbitofrontal cortex, and NAcc (Mychasiuk et al., 2013; Castino et al., 2018). In the prefrontal cortex, nicotine self-administration was correlated with decreased histone methylation at the H3K27me3 and $\mathrm{H} 3 \mathrm{~K} 9 \mathrm{me} 2$ marks in the $\mathrm{BDNF}$ and cyclin-dependent kinase 5 gene, but in contrast, withdrawal from nicotine elicited a decrease in H3K14 acetylation at the BDNF promoter (Castino et al., 2018), demonstrating different changes across stages of drug use. Following nicotine abstinence, histone deacetylase inhibitor administration results in an attenuation of cue-induced reinstatement (Castino et al., 2015), suggesting a further role for epigenetic factors in relapse-associated behaviors. Thus, altered gene expression due to changes in the epigenetic landscape may contribute to the development and/or maintenance of nicotine dependence, withdrawal effects, or vulnerability to relapse.

Finally, it is worthwhile to note that in utero exposure to nicotine has also been associated with epigenetic changes. Because of the longevity of these changes, the effects of such regulation may lead to detrimental outcomes persisting through adolescence and into adulthood. For example, differential methylation patterns have been documented in blood samples following exposure to prenatal maternal smoking, with associations noted at $\mathrm{CpG}$ sites in the genes $M Y O 1 G$, FRMD4A, CYP1A1, CNTNAP2, ARL4C, AHRR, TIFAB, MDM4, $A X 748264$, DRD1, FTO (Richmond et al., 2018). Of note, some epigenetic changes associated with maternal tobacco exposure have been replicated in other studies in humans, can persist across the lifespan, and have been linked to schizophreniaassociated symptomology (Joubert et al., 2016; Richmond et al., 2018; Tehranifar et al., 2018; Wiklund et al., 2019). However, several caveats must be considered for human studies based on numerous potentially confounding factors, such as comorbidity of drug use, socioeconomic status, nutritional deficits, stress, etc., and as such, it is important to validate such findings in a more controlled model system. Further, epigenetic changes detected in blood samples may not relate

\section{REFERENCES}

Ables, J. L., Gorlich, A., Antolin-Fontes, B., Wang, C., Lipford, S. M., Riad, M. H., et al. (2017). Retrograde inhibition by a specific subset of interpeduncular to the processes occurring in the brain. Thus, additional studies have begun to validate and extend these findings with studies in rodents. For instance, nicotine administration to pregnant dams results in hypomethylated DNA in the fetal cortex (Chatterton et al., 2017), supporting the notion of brainrelevant epigenetic changes with nicotine exposure. Moreover, nicotine exposure in male mice, before copulation, leads to their offspring exhibiting methylation changes in hippocampal genes related to neural development and plasticity, which is correlated with increased fear conditioning and decreased nicotine reinforcement (Goldberg et al., 2021). Thus, these studies suggest that nicotine can induce epigenetic changes in early development through direct actions in utero in pregnant females, or by altering gene expression in male sperm before fertilization. However, future studies are necessary to more specifically delineate the causative effects of such changes in the epigenetic landscape.

\section{CONCLUSIONS}

The impact of nicotine on cholinergic function and gene expression has been shown to modulate multiple downstream effects that can contribute to different facets of nicotine dependence. The relationship between nicotine-seeking behavior and gene expression is cell type-specific, sex-specific, developmental, and bidirectional. Moreover, nicotine's actions on the cholinergic system can affect cognition, feeding, learning and memory, attention, and anxiety- and depression-associated symptoms, in addition to nicotine reinforcement and seeking behavior, and as such, the implications of nicotine use on gene expression is extensive and multifaceted (Changeux et al., 1998; Picciotto et al., 2002; Mineur et al., 2011; Koukouli et al., 2017). Thus, future efforts to more fully characterize the changes in gene expression occurring in specific cell types and brain regions at various stages along the drug use trajectory will be necessary to ascertain a comprehensive understanding of the intersectional and bidirectional contributions that regulate the relationship between gene expression and behavior. Through these analyses, novel gene targets may be identified as a foundation for more efficacious therapeutic development efforts.

\section{AUTHOR CONTRIBUTIONS}

All authors contributed to the article and approved the submitted version.

\section{FUNDING}

This work was supported by grants from the National Institute of Health (NIH) National Institute on Drug Abuse (R01DA051831 to CF and F31DA050436 to YS).

$\alpha 5$ nicotinic neurons regulates nicotine preference. Proc. Natl. Acad. Sci. U S A 114, 13012-13017. doi: 10.1073/pnas.1717506114

Adeluyi, A., Guerin, L., Fisher, M. L., Galloway, A., Cole, R. D., Chan, S. S. L., et al. (2019). Microglia morphology and proinflammatory signaling in 
the nucleus accumbens during nicotine withdrawal. Sci. Adv. 5:eaax7031. doi: 10.1126/sciadv.aax7031

Adriani, W., Spijker, S., Deroche-Gamonet, V., Laviola, G., Le Moal, M., Smit, A. B., et al. (2003). Evidence for enhanced neurobehavioral vulnerability to nicotine during periadolescence in rats. J. Neurosci. 23, 4712-4716. doi: 10.1523/JNEUROSCI.23-11-04712.2003

Akkus, F., Ametamey, S. M., Treyer, V., Burger, C., Johayem, A., Umbricht, D., et al. (2013). Marked global reduction in mGluR5 receptor binding in smokers and ex-smokers determined by [11C]ABP688 positron emission tomography. Proc. Natl. Acad. Sci. U S A 110, 737-742. doi: 10.1073/pnas.1210984110

Al'Absi, M., Lemieux, A., Nakajima, M., Hatsukami, D. K., and Allen, S. (2015). Circulating leptin and pain perception among tobacco-dependent individuals. Biol. Psychol. 107, 10-15. doi: 10.1016/j.biopsycho.2015.02.008

Alajaji, M., Lazenka, M. F., Kota, D., Wise, L. E., Younis, R. M., Carroll, F. I., et al. (2016). Early adolescent nicotine exposure affects later-life cocaine reward in mice. Neuropharm 105, 308-317. doi: 10.1016/j.neuropharm.2016.01.032

Amos, C. I., Wu, X., Broderick, P., Gorlov, I. P., Gu, J., Eisen, T., et al. (2008). Genome-wide association scan of tag SNPs identifies a susceptibility locus for lung cancer at 15q25.1. Nat. Genet. 40, 616-622. doi: 10.1038/ng.109

Anderson, K. R., Hoffman, K. M., and Miwa, J. M. (2020). Modulation of cholinergic activity through lynx prototoxins: implications for cognition and anxiety regulation. Neuropharmacology 174:108071. doi: 10.1016/j. neuropharm.2020.108071

Antolin-Fontes, B., Ables, J. L., Görlich, A., and Ibañez-Tallon, I. (2015). The habenulo-interpeduncular pathway in nicotine aversion and withdrawal. Neuropharmacology 96, 213-222. doi: 10.1016/j.neuropharm.2014.11.019

Ariyoshi, N., Miyamoto, M., Umetsu, Y., Kunitoh, H., Dosaka-Akita, H., Sawamura, Y., et al. (2002). Genetic polymorphism of CYP2A6 gene and tobacco-induced lung cancer risk in male smokers. Cancer Epidemiol. Biomarkers Prev. 11, 890-894.

Ávila-Ruiz, T., Carranza, V., Gustavo, L. L., Limón, D. I., Martínez, I., Flores, G., et al. (2014). Chronic administration of nicotine enhances NMDA-activated currents in the prefrontal cortex and core part of the nucleus accumbens of rats. Synapse 68, 248-256. doi: 10.1002/syn.21726

Bai, Y., Liu, X., Qi, X., Liu, X., Peng, F., Li, H., et al. (2019). PDIA6 modulates apoptosis and autophagy of non-small cell lung cancer cells via the MAP4K1/JNK signaling pathway. EBioMedicine 42, 311-325. doi: 10.1016/j. ebiom.2019.03.045

Bannon, M., Kapatos, G., and Albertson, D. (2005). Gene expression profiling in the brains of human cocaine abusers. Addict. Biol. 10, 119-126. doi: 10.1080/13556210412331308921

Baur, K., Hach, A., Bernardi, R. E., Spanagel, R., Bading, H., and Bengtson, C. P. (2018). c-Fos marking of identified midbrain neurons coactive after nicotine administration in-vivo. J. Comp. Neurol. 526, 2019-2031. doi: 10.1002/cne. 24471

Ben-David, Y., Mizrachi, T., Kagan, S., Krisher, T., Cohen, E., Brenner, T., et al. (2016). RIC-3 expression and splicing regulate $\mathrm{nAChR}$ functional expression. Mol. Brain 9:47. doi: 10.1186/s13041-016-0231-5

Berrendero, F., Plaza-Zabala, A., Galeote, L., Flores, Á., Bura, S. A., Kieffer, B. L., et al. (2012). Influence of $\delta$-opioid receptors in the behavioral effects of nicotine. Neuropsychopharmacology 37, 2332-2344. doi: 10.1038/npp.2012.88

Bertagna, N. B., Dos Santos, P. G. C., Queiroz, R. M., Fernandes, G. J. D., Cruz, F. C., and Miguel, T. T. (2021). Involvement of the ventral, but not dorsal, hippocampus in anxiety-like behaviors in mice exposed to the elevated plus maze: participation of CRF1 receptor and PKA pathway. Pharmacol. Rep. 73, 57-72. doi: 10.1007/s43440-020-00182-3

Blake, M. G., and Boccia, M. M. (2018). Basal forebrain cholinergic system and memory. Curr. Top. Behav. Neurosci. 37, 253-273. doi: 10.1007/7854_ 2016_467

Brunzell, D. H., Mineur, Y. S., Neve, R. L., and Picciotto, M. R. (2009). Nucleus accumbens CREB activity is necessary for nicotine conditioned place preference. Neuropsychopharmacology 34, 1993-2001. doi: 10.1038/npp. 2009.11

Cammaerts, S., Strazisar, M., Smets, B., Weckhuysen, S., Nordin, A., De Jonghe, P., et al. (2015). Schizophrenia-associated MIR204 regulates noncoding RNAs and affects neurotransmitter and ion channel gene sets. PLoS One 10:e0144428. doi: 10.1371 /journal.pone. 0144428
Cao, J., Wang, J., Dwyer, J. B., Gautier, N. M., Wang, S., Leslie, F. M., et al. (2013). Gestational nicotine exposure modifies myelin gene expression in the brains of adolescent rats with sex differences. Transl. Psychiatry 3:e247. doi: 10.1038/tp. 2013.21

Carboni, L., Romoli, B., Bate, S. T., Romualdi, P., and Zoli, M. (2018). Increased expression of CRF and CRF-receptors in dorsal striatum, hippocampus and prefrontal cortex after the development of nicotine sensitization in rats. Drug Alcohol Depend. 189, 12-20. doi: 10.1016/j.drugalcdep.2018.04.027

Casserly, A. P., Tsuji, J., Zhao-Shea, R., Smith, C. B., Molas, S., Tapper, A. R., et al. (2020). Integrated miRNA-/mRNA-seq of the habenulo-interpeduncular circuit during acute nicotine withdrawal. Sci. Rep. 10:813. doi: 10.1038/s41598020-57907-w

Castino, M. R., Baker-Andresen, D., Ratnu, V. S., Shevchenko, G., Morris, K. V., Bredy, T. W., et al. (2018). Persistent histone modifications at the BDNF and Cdk-5 promoters following extinction of nicotine-seeking in rats. Genes Brain Behav. 17, 98-106. doi: 10.1111/gbb.12421

Castino, M. R., Cornish, J. L., and Clemens, K. J. (2015). Inhibition of histone deacetylases facilitates extinction and attenuates reinstatement of nicotine self-administration in rats. PLoS One 10:e0124796. doi: 10.1371/journal.pone. 0124796

Chan, Y. L., Saad, S., Pollock, C., Oliver, B., Al-Odat, I., Zaky, A. A., et al. (2016). Impact of maternal cigarette smoke exposure on brain inflammation and oxidative stress in male mice offspring. Sci. Rep. 6:25881. doi: 10.1038/srep25881

Changeux, J.-P. (2010). Nicotine addiction and nicotinic receptors: lessons from genetically modified mice. Nat. Rev. Neurosci. 11, 389-401. doi: $10.1038 / \mathrm{nrn} 2849$

Changeux, J. P., Bertrand, D., Corringer, P. J., Dehaene, S., Edelstein, S., Lena, C., et al. (1998). Brain nicotinic receptors: structure and regulation, role in learning and reinforcement. Brain Res. Rev. 26, 198-216. doi: 10.1016/s01650173(97)00040-4

Chatterton, Z., Hartley, B. J., Seok, M.-H., Mendelev, N., Chen, S., Milekic, M., et al. (2017). In utero exposure to maternal smoking is associated with DNA methylation alterations and reduced neuronal content in the developing fetal brain. Epigenetics Chromatin 10:4. doi: 10.1186/s13072-017-0111-y

Chen, Y.-C., Fowler, J. P., Wang, J., Watson, C. J. W., Sherafat, Y., Staben, A., et al. (2020). The novel CYP2A6 inhibitor, DLCI-1, decreases nicotine self-administration in mice. J. Pharmacol. Exp. Ther. 372, 21-29. doi: 10.1124/jpet.119.260653

Chen, H., Luo, R., Gong, S., Matta, S. G., and Sharp, B. M. (2014). Protection genes in nucleus accumbens shell affect vulnerability to nicotine self-administration across isogenic strains of adolescent rat. PLoS One 9:e86214. doi: 10.1371/journal.pone.0086214

Clarke, P. B., Hamill, G. S., Nadi, N. S., Jacobowitz, D. M., and Pert, A. (1986). 3H-nicotine- and 125I- $\alpha$-bungarotoxin-labeled nicotinic receptors in the interpeduncular nucleus of rats: II. Effects of habenular deafferentation. J. Comp. Neurol. 251, 407-413. doi: 10.1002/cne.902510311

Clarke, P. B., Schwartz, R. D., Paul, S. M., Pert, C. B., and Pert, A. (1985). Nicotinic binding in rat brain: autoradiographic comparison of $\left.{ }^{[3 H}\right]_{\text {acetylcholine, }}{ }^{[3 H]}$ nicotine, and ${ }^{[125 I]}-\alpha$-bungarotoxin. J. Neurosci. 5, 1307-1315. doi: 10.1523/JNEUROSCI.05-05-01307.1985

Cole, A. J., Saffen, D. W., Baraban, J. M., and Worley, P. F. (1989). Rapid increase of an immediate early gene messenger RNA in hippocampal neurons by synaptic NMDA receptor activation. Nature 340, 474-476. doi: 10.1038/340474a0

Cole, R. D., Zimmerman, M., Matchanova, A., Kutlu, M. G., Gould, T. J., and Parikh, V. (2020). Cognitive rigidity and BDNF-mediated frontostriatal glutamate neuroadaptations during spontaneous nicotine withdrawal. Neuropsychopharmacology $\quad 45, \quad 866-876$. doi: 10.1038/s41386-0190574-6

Corley, J., Cox, S. R., Harris, S. E., Hernandez, M. V., Maniega, S. M., Bastin, M. E., et al. (2019). Epigenetic signatures of smoking associate with cognitive function, brain structure, and mental and physical health outcomes in the Lothian Birth Cohort 1936. Transl. Psychiatry 9:248. doi: 10.1038/s41398-0190576-5

Corradi, J., and Bouzat, C. (2016). Understanding the bases of function and modulation of $\alpha 7$ nicotinic receptors: implications for drug discovery. Mol. Pharmacol. 90, 288-299. doi: 10.1124/mol.116.104240 
Correa, V. L., Flores, R. J., Carcoba, L. M., Arreguin, M. C., and O’Dell, L. E. (2019). Sex differences in cholinergic systems in the interpeduncular nucleus following nicotine exposure and withdrawal. Neuropharmacology 158:107714. doi: 10.1016/j.neuropharm.2019.107714

Cross, S. J., Linker, K. E., and Leslie, F. M. (2017). Sex-dependent effects of nicotine on the developing brain. J. Neurosci. Res. 95, 422-436. doi: 10.1002/jnr.23878

Damaj, M. I., Kao, W., and Martin, B. R. (2003). Characterization of spontaneous and precipitated nicotine withdrawal in the mouse. J. Pharmacol. Exp. Ther. 307, 526-534. doi: 10.1124/jpet.103.054908

Dau, A., Komal, P., Truong, M., Morris, G., Evans, G., and Nashmi, R. (2013). RIC-3 differentially modulates $\alpha 4 \beta 2$ and $\alpha 7$ nicotinic receptor assembly, expression, and nicotine-induced receptor upregulation. BMC Neurosci. 14:47. doi: 10.1186/1471-2202-14-47

Deba, F., Ali, H. I., Tairu, A., Ramos, K., Ali, J., and Hamouda, A. K. (2018). LY2087101 and dFBr share transmembrane binding sites in the $(\alpha 4) 3(\beta 2) 2$ nicotinic acetylcholine receptor. Sci. Rep. 8:1249. doi: 10.1038/s41598-018-19790-4

Dehkordi, O., Rose, J. E., Millis, R. M., Dalivand, M. M., and Johnson, S. M. (2018). GABAergic neurons as putative neurochemical substrate mediating aversive effects of nicotine. J. Alcohol. Drug Depend. 6:312. doi: 10.4172/2329-6488. 1000312

Delbart, F., Brams, M., Gruss, F., Noppen, S., Peigneur, S., Boland, S., et al. (2018). An allosteric binding site of the $\alpha 7$ nicotinic acetylcholine receptor revealed in a humanized acetylcholine-binding protein. J. Biol. Chem. 293, 2534-2545. doi: $10.1074 /$ jbc.M117.815316

Demars, M. P., and Morishita, H. (2014). Cortical parvalbumin and somatostatin GABA neurons express distinct endogenous modulators of nicotinic acetylcholine receptors. Mol. Brain 7:75. doi: 10.1186/s13041-014-0075-9

Dessaud, E., Salaün, D., Gayet, O., Chabbert, M., and deLapeyrière, O. (2006). Identification of lynx2, a novel member of the ly-6/neurotoxin superfamily, expressed in neuronal subpopulations during mouse development. Mol. Cell. Neurosci. 31, 232-242. doi: 10.1016/j.mcn.2005.09.010

Dhungel, B., Ramlogan-Steel, C. A., Layton, C. J., and Steel, J. C. (2018). MicroRNA199a-based post-transcriptional detargeting of gene vectors for hepatocellular carcinoma. Mol. Ther. Nucleic Acids 13, 78-88. doi: 10.1016/j. omtn.2018.08.016

Doura, M. B., Luu, T. V., Lee, N. H., and Perry, D. C. (2010). Persistent gene expression changes in ventral tegmental area of adolescent but not adult rats in response to chronic nicotine. Neuroscience 170, 503-513. doi: 10.1016/j. neuroscience.2010.06.071

Dukes, A. J., Fowler, J. P., Lallai, V., Pushkin, A. N., and Fowler, C. D. (2020). Adolescent cannabinoid and nicotine exposure differentially alters adult nicotine self-administration in males and females. Nicotine Tob. Res. 22, 1364-1373. doi: 10.1093/ntr/ntaa084

Elayouby, K. S., Ishikawa, M., Dukes, A. J., Smith, A. C., Lu, Q., Fowler, C. D., et al. (2021). $\alpha 3^{*}$ nicotinic acetylcholine receptors in the habenulainterpeduncular nucleus circuit regulate nicotine intake. J. Neurosci. 41, 1779-1787. doi: 10.1523/JNEUROSCI.0127-19.2020

Ernst, M., Moolchan, E. T., and Robinson, M. L. (2001). Behavioral and neural consequences of prenatal exposure to nicotine. J. Am. Acad. Child Adolesc. Psychiatry 40, 630-641. doi: 10.1097/00004583-200106000-00007

Fang, C.-P., Wang, S.-C., Tsou, H.-H., Chung, R.-H., Hsu, Y.-T., Liu, S. C., et al. (2020). Genetic polymorphisms in the opioid receptor delta 1 (OPRD1) gene are associated with methadone dose in methadone maintenance treatment for heroin dependence. J. Hum. Genet. 65, 381-386. doi: 10.1038/s10038-0190718-x

Fasoli, F., Moretti, M., Zoli, M., Pistillo, F., Crespi, A., Clementi, F., et al. (2016). In vivo chronic nicotine exposure differentially and reversibly affects upregulation and stoichiometry of $\alpha 4 \beta 2$ nicotinic receptors in cortex and thalamus. Neuropharmacology 108, 324-331. doi: 10.1016/j.neuropharm.2016. 04.048

Faulkner, P., Ghahremani, D. G., Tyndale, R. F., Hellemann, G., and London, E. D. (2018). Functional connectivity of the raphe nuclei: link to tobacco withdrawal in smokers. Int. J. Neuropsychopharmacol. 21, 800-808. doi: 10.1093/ijnp/pyy054

Feduccia, A. A., Chatterjee, S., and Bartlett, S. E. (2012). Neuronal nicotinic acetylcholine receptors: neuroplastic changes underlying alcohol and nicotine addictions. Front. Mol. Neurosci. 5:83. doi: 10.3389/fnmol.2012.00083
Ferrari, R., Le Novère, N., Picciotto, M. R., Changeux, J. P., and Zoli, M. (2002). Acute and long-term changes in the mesolimbic dopamine pathway after systemic or local single nicotine injections. Eur. J. Neurosci. 15, 1810-1818. doi: 10.1046/j.1460-9568.2001.02009.x

Fisher, M. L., LeMalefant, R. M., Zhou, L., Huang, G., and Turner, J. R. (2017). Distinct roles of CREB within the ventral and dorsal hippocampus in mediating nicotine withdrawal phenotypes. Neuropsychopharmacology 42, 1599-1609. doi: 10.1038/npp.2016.257

Fornari, A., Pedrazzi, P., Lippi, G., Picciotto, M. R., Zoli, M., and Zini, I. (2007) Nicotine withdrawal increases body weight, neuropeptide $Y$ and Agouti-related protein expression in the hypothalamus and decreases uncoupling protein-3 expression in the brown adipose tissue in high-fat fed mice. Neurosci. Lett. 411, 72-76. doi: 10.1016/j.neulet.2006.10.014

Fowler, C. D., and Kenny, P. J. (2011). Intravenous nicotine self-administration and cue-induced reinstatement in mice: effects of nicotine dose, rate of drug infusion and prior instrumental training. Neuropharmacology 61, 687-698. doi: 10.1016/j.neuropharm.2011.05.012

Fowler, C. D., and Kenny, P. J. (2014). Nicotine aversion: neurobiological mechanisms and relevance to tobacco dependence vulnerability. Neuropharmacology 76, 533-544. doi: 10.1016/j.neuropharm.2013.09.008

Fowler, C. D., Lu, Q., Johnson, P. M., Marks, M. J., and Kenny, P. J. (2011). Habenular $\alpha 5$ nicotinic receptor subunit signalling controls nicotine intake. Nature 471, 597-601. doi: 10.1038/nature09797

Fowler, C. D., Tuesta, L., and Kenny, P. J. (2013). Role of $\alpha 5^{\star}$ nicotinic acetylcholine receptors in the effects of acute and chronic nicotine treatment on brain reward function in mice. Psychopharmacology 229, 503-513. doi: 10.1007/s00213-013-3235-1

Fowler, C. D., Turner, J. R., and Imad Damaj, M. (2020). Molecular mechanisms associated with nicotine pharmacology and dependence. Handb. Exp. Pharmacol. 258, 373-393. doi: 10.1007/164_2019_252

Frahm, S., Slimak, M. A., Ferrarese, L., Santos-Torres, J., Antolin-Fontes, B., Auer, S., et al. (2011). Aversion to nicotine is regulated by the balanced activity of $\beta 4$ and $\alpha 5$ nicotinic receptor subunits in the medial habenula. Neuron 70 , 522-535. doi: 10.1016/j.neuron.2011.04.013

Freathy, R. M., Kazeem, G. R., Morris, R. W., Johnson, P. C., Paternoster, L., Ebrahim, S., et al. (2011). Genetic variation at CHRNA5-CHRNA3CHRNB4 interacts with smoking status to influence body mass index. Int. J. Epidemiol. 40, 1617-1628. doi: 10.1093/ije/dyr077

Freathy, R. M., Ring, S. M., Shields, B., Galobardes, B., Knight, B., Weedon, M. N., et al. (2009). A common genetic variant in the 15q24 nicotinic acetylcholine receptor gene cluster (CHRNA5-CHRNA3-CHRNB4) is associated with a reduced ability of women to quit smoking in pregnancy. Hum. Mol. Genet. 18, 2922-2927. doi: 10.1093/hmg/ddp216

Fuentealba, J., Olivares, R., Alés, E., Tapia, L., Rojo, J., Arroyo, G., et al. (2004). A choline-evoked $\left[\mathrm{Ca}^{2+}\right] \mathrm{c}$ signal causes catecholamine release and hyperpolarization of chromaffin cells. FASEB J. 18, 1468-1470. doi: 10.1096/fj. 04-1828fje

Funk, D., Coen, K., Tamadon, S., Hope, B. T., Shaham, Y., and Le, A. D. (2016). Role of central amygdala neuronal ensembles in incubation of nicotine craving. J. Neurosci. 36, 8612-8623. doi: 10.1523/JNEUROSCI.150516.2016

Garcia-Arcos, I., Geraghty, P., Baumlin, N., Campos, M., Dabo, A. J., Jundi, B., et al. (2016). Chronic electronic cigarette exposure in mice induces features of COPD in a nicotine-dependent manner. Thorax 71, 1119-1129. doi: 10.1136/thoraxjnl-2015-208039

George, A. A., Bloy, A., Miwa, J. M., Lindstrom, J. M., Lukas, R. J., and Whiteaker, P. (2017). Isoform-specific mechanisms of $\alpha 3 \beta 4^{*}$-nicotinic acetylcholine receptor modulation by the prototoxin lynx1. FASEB J. 31, 1398-1420. doi: 10.1096/fj.201600733R

George, O., Ghozland, S., Azar, M. R., Cottone, P., Zorrilla, E. P., Parsons, L. H., et al. (2007). CRF CRF1 system activation mediates withdrawal-induced increases in nicotine self-administration in nicotine-dependent rats. Proc. Natl. Acad. Sci. U S A 104, 17198-17203. doi: 10.1073/pnas.0707585104

Gipson, C. D., and Fowler, C. D. (2020). Nicotinic receptors underlying nicotine dependence: evidence from transgenic mouse models. Curr. Top. Behav. Neurosci. 45, 101-121. doi: 10.1007/7854_2020_134

Gipson, C. D., Reissner, K. J., Kupchik, Y. M., Smith, A. C., Stankeviciute, N., Hensley-Simon, M. E., et al. (2013). Reinstatement of nicotine seeking is 
mediated by glutamatergic plasticity. Proc. Natl. Acad. Sci. U S A 110, 9124-9129. doi: 10.1073/pnas.1220591110

Goldberg, L. R., Zeid, D., Kutlu, M. G., Cole, R. D., Lallai, V., Sebastian, A., et al. (2021). Paternal nicotine enhances fear memory, reduces nicotine administration, and alters hippocampal genetic and neural function in offspring. Addict. Biol. 26:e12859. doi: 10.1111/adb.12859

Goriounova, N. A., and Mansvelder, H. D. (2012). Short- and long-term consequences of nicotine exposure during adolescence for prefrontal cortex neuronal network function. Cold Spring Harb. Perspect. Med. 2:a012120. doi: 10.1101/cshperspect.a012120

Gould, T. J., Wilkinson, D. S., Yildirim, E., Blendy, J. A., and Adoff, M. D. (2014). Dissociation of tolerance and nicotine withdrawal-associated deficits in contextual fear. Brain Res. 1559, 1-10. doi: 10.1016/j.brainres.2014. 02.038

Grady, S. R., Moretti, M., Zoli, M., Marks, M. J., Zanardi, A., Pucci, L., et al. (2009). Rodent habenulo-interpeduncular pathway expresses a large variety of uncommon nAChR subtypes, but only the $\alpha 3 \beta 4^{*}$ and $\alpha 3 \beta 3 \beta 4^{*}$ subtypes mediate acetylcholine release. J. Neurosci. $29,2272-2282$. doi: 10.1523/JNEUROSCI.5121-08.2009

Grieder, T. E., Herman, M. A., Contet, C., Tan, L. A., Vargas-Perez, H., Cohen, A., et al. (2014). VTA CRF neurons mediate the aversive effects of nicotine withdrawal and promote intake escalation. Nat. Neurosci. 17, 1751-1758. doi: $10.1038 / \mathrm{nn} .3872$

Guo, Q., Wang, D., He, X., Feng, Q., Lin, R., Xu, F., et al. (2015). Wholebrain mapping of inputs to projection neurons and cholinergic interneurons in the dorsal striatum. PLoS One 10:e0123381. doi: 10.1371/journal.pone.01 23381

Haga, T. (2013). Molecular properties of muscarinic acetylcholine receptors. Proc. Jpn. Acad. Ser. B Phys. Biol. Sci. 89, 226-256. doi: 10.2183/pjab. 89.226

Haga, K., Kruse, A. C., Asada, H., Yurugi-Kobayashi, T., Shiroishi, M., Zhang, C., et al. (2012). Structure of the human M2 muscarinic acetylcholine receptor bound to an antagonist. Nature 482, 547-551. doi: 10.1038/nature 10753

Henderson, B. J., Wall, T. R., Henley, B. M., Kim, C. H., McKinney, S., and Lester, H. A. (2017). Menthol enhances nicotine reward-related behavior by potentiating nicotine-induced changes in nAChR function, nAChR upregulation, and DA neuron excitability. Neuropsychopharmacology 42, 2285-2291. doi: 10.1038/npp.2017.72

Hendrickson, L. M., Guildford, M. J., and Tapper, A. R. (2013). Neuronal nicotinic acetylcholine receptors: common molecular substrates of nicotine and alcohol dependence. Front. Psychiatry 4:29. doi: 10.3389/fpsyt.2013.00029

Herd, N., Borland, R., and Hyland, A. (2009). Predictors of smoking relapse by duration of abstinence: findings from the International Tobacco Control (ITC) four country survey. Addiction 104, 2088-2099. doi: 10.1111/j.1360-0443.2009. 02732.x

Herkenham, M., and Nauta, W. J. (1979). Efferent connections of the habenular nuclei in the rat. J. Comp. Neurol. 187, 19-47. doi: 10.1002/cne.901870103

Holford, M., Auer, S., Laqua, M., and Ibañez-Tallon, I. (2009). Manipulating neuronal circuits with endogenous and recombinant cell-surface tethered modulators. Front. Mol. Neurosci. 2:21. doi: 10.3389/neuro.02. 021.2009

Hosur, V., Leppanen, S., Abutaha, A., and Loring, R. H. (2009). Gene regulation of $\alpha 4 \beta 2$ nicotinic receptors: microarray analysis of nicotine-induced receptor up-regulation and anti-inflammatory effects. J. Neurochem. 111, 848-858. doi: 10.1111/j.1471-4159.2009.06373.x

Huang, H., Xu, Y., and van den Pol, A. N. (2011). Nicotine excites hypothalamic arcuate anorexigenic proopiomelanocortin neurons and orexigenic neuropeptide Y neurons: similarities and differences. J. Neurophysiol. 106, 1191-1202. doi: 10.1152/jn.00740.2010

Hulme, E. C., Birdsall, N. J., and Buckley, N. J. (1990). Muscarinic receptor subtypes. Annu. Rev. Pharmacol. Toxicol. 30, 633-673. doi: 10.1146/annurev. pa.30.040190.003221

Jackson, K. J., Sanjakdar, S. S., Muldoon, P. P., McIntosh, J. M., and Damaj, M. I. (2013). The $\alpha 3 \beta 4^{*}$ nicotinic acetylcholine receptor subtype mediates nicotine reward and physical nicotine withdrawal signs independently of the $\alpha 5$ subunit in the mouse. Neuropharmacology 70, 228-235. doi: 10.1016/j.neuropharm. 2013.01.017
Javadi-Paydar, M., Kerr, T. M., Harvey, E. L., Cole, M., and Taffe, M. A. (2019). Effects of nicotine and THC vapor inhalation administered by an electronic nicotine delivery system (ENDS) in male rats. Drug Alcohol Depend. 198, 54-62. doi: 10.1016/j.drugalcdep.2019.01.027

Ji, Z., Li, H., Yang, Z., Huang, X., Ke, X., Ma, S., et al. (2019). Kibra modulates learning and memory via binding to dendrin. Cell Rep. 26, 2064.e7-2077.e7. doi: 10.1016/j.celrep.2019.01.097

Jones, I. W., and Wonnacott, S. (2004). Precise localization of $\alpha 7$ nicotinic acetylcholine receptors on glutamatergic axon terminals in the rat ventral tegmental area. J. Neurosci. 24, 11244-11252. doi: 10.1523/JNEUROSCI.300904.2004

Joubert, B. R., Felix, J. F., Yousefi, P., Bakulski, K. M., Just, A. C., Breton, C., et al. (2016). DNA methylation in newborns and maternal smoking in pregnancy: genome-wide consortium meta-analysis. Am. J. Hum. Genet. 98, 680-696. doi: 10.1016/j.ajhg.2016.02.019

Jung, Y., Hsieh, L. S., Lee, A. M., Zhou, Z., Coman, D., Heath, C. J., et al. (2016). An epigenetic mechanism mediates developmental nicotine effects on neuronal structure and behavior. Nat. Neurosci. 19, 905-914. doi: 10.1038/nn.4315

Kane, J. K., Hwang, Y., Konu, O., Loughlin, S. E., Leslie, F. M., and Li, M. D. (2005). Regulation of Homer and group I metabotropic glutamate receptors by nicotine. Eur. J. Neurosci. 21, 1145-1154. doi: 10.1111/j.1460-9568.2005. 03945.x

Kenny, P. J. (2007). Brain reward systems and compulsive drug use. Trends Pharmacol. Sci. 28, 135-141. doi: 10.1016/j.tips.2007.01.008

Kenny, P. J., Chartoff, E., Roberto, M., Carlezon, W. A. Jr., and Markou, A. (2009). NMDA receptors regulate nicotine-enhanced brain reward function and intravenous nicotine self-administration: role of the ventral tegmental area and central nucleus of the amygdala. Neuropsychopharmacology 34, 266-281. doi: $10.1038 /$ npp. 2008.58

Kenny, P. J., and Markou, A. (2006). Nicotine self-administration acutely activates brain reward systems and induces a long-lasting increase in reward sensitivity. Neuropsychopharmacology 31, 1203-1211. doi: 10.1038/sj.npp. 1300905

Klink, R., de Kerchove d'Exaerde, A., Zoli, M., and Changeux, J. P. (2001). Molecular and physiological diversity of nicotinic acetylcholine receptors in the midbrain dopaminergic nuclei. J. Neurosci. 21, 1452-1463. doi: 10.1523/JNEUROSCI.21-05-01452.2001

Kobayashi, A., Parker, R. L., Wright, A. P., Brahem, H., Ku, P., Oliver, K. M., et al. (2014). Lynx1 supports neuronal health in the mouse dorsal striatum during aging: an ultrastructural investigation. J. Mol. Neurosci. 53, 525-536. doi: 10.1007/s12031-014-0352-1

Koob, G. F., and Volkow, N. D. (2010). Neurocircuitry of addiction. Neuropsychopharmacology 35, 217-238. doi: 10.1038/npp.2009.110

Koukouli, F., Rooy, M., Tziotis, D., Sailor, K. A., O’Neill, H. C., Levenga, J., et al. (2017). Nicotine reverses hypofrontality in animal models of addiction and schizophrenia. Nat. Med. 23, 347-354. doi: 10.1038/nm.4274

Kovács, K. J. (1998). c-Fos as a transcription factor: a stressful (re)view from a functional map. Neurochem. Int. 33, 287-297. doi: 10.1016/s01970186(98)00023-0

Kyte, S. L., and Gewirtz, D. A. (2018). The influence of nicotine on lung tumor growth, cancer chemotherapy, and chemotherapy-induced peripheral neuropathy. J. Pharmacol. Exp. Ther. 366, 303-313. doi: 10.1124/jpet.118. 249359

Lallai, V., Grimes, N., Fowler, J. P., Sequeira, P. A., Cartagena, P., Limon, A., et al. (2019). Nicotine acts on cholinergic signaling mechanisms to directly modulate choroid plexus function. eNeuro 6:ENEURO.0051-19.2019. doi: 10.1523/ENEURO.0051-19.2019

Le Novère, N., and Changeux, J. P. (1995). Molecular evolution of the nicotinic acetylcholine receptor: an example of multigene family in excitable cells. J. Mol. Evol. 40, 155-172. doi: 10.1007/BF00167110

Lester, H. A., Xiao, C., Srinivasan, R., Son, C. D., Miwa, J., Pantoja, R., et al. (2009). Nicotine is a selective pharmacological chaperone of acetylcholine receptor number and stoichiometry. Implications for drug discovery. AAPS J. 11, 167-177. doi: 10.1208/s12248-009-9090-7

Leyrer-Jackson, J. M., Holter, M., Overby, P. F., Newbern, J. M., Scofield, M. D., Olive, M. F., et al. (2020). Accumbens cholinergic interneurons mediate cue-induced nicotine seeking and associated glutamatergic plasticity. eNeuro 8:ENEURO.0276-20.2020. doi: 10.1523/ENEURO.0276-20.2020 
Li, T., Pan, H., and Li, R. (2016). The dual regulatory role of miR-204 in cancer. Tumour Biol. 37, 11667-11677. doi: 10.1007/s13277-016-5144-5

Lindstrom, J. (1997). Nicotinic acetylcholine receptors in health and disease. Mol. Neurobiol. 15, 193-222. doi: 10.1007/BF02740634

Lipovsek, M., Fierro, A., Pérez, E. G., Boffi, J. C., Millar, N. S., Fuchs, P. A., et al. (2014). Tracking the molecular evolution of calcium permeability in a nicotinic acetylcholine receptor. Mol. Biol. Evol. 31, 3250-3265. doi: $10.1093 / \mathrm{molbev} / \mathrm{msu} 258$

Lipsius, S. L. (1982). Acetylcholine and potassium- 42 movements in right atrial muscle of the guinea pig. J. Auton. Nerv. Syst. 5, 279-289. doi: 10.1016/01651838(82)90071-6

Liu, T., Wu, X., Chen, T., Luo, Z., and Hu, X. (2018). Downregulation of DNMT3A by miR-708-5p inhibits lung cancer stem cell-like phenotypes through repressing wnt//-catenin signaling. Clin. Cancer Res. 24, 1748-1760. doi: 10.1158/1078-0432.CCR-17-1169

Locker, A. R., Marks, M. J., Kamens, H. M., and Klein, L. C. (2016). Exposure to nicotine increases nicotinic acetylcholine receptor density in the reward pathway and binge ethanol consumption in C57BL/6J adolescent female mice. Brain Res. Bull. 123, 13-22. doi: 10.1016/j.brainresbull.2015. 09.009

Lubbers, B. R., van Mourik, Y., Schetters, D., Smit, A. B., De Vries, T. J., and Spijker, S. (2014). Prefrontal $\gamma$-aminobutyric acid type A receptor insertion controls cue-induced relapse to nicotine seeking. Biol. Psychiatry 76, 750-758. doi: 10.1016/j.biopsych.2014.02.001

Mahler, S. V., Brodnik, Z. D., Cox, B. M., Buchta, W. C., Bentzley, A. S., Quintanilla, J., et al. (2019). Chemogenetic manipulations of ventral tegmental area dopamine neurons reveal multifaceted roles in cocaine abuse. J. Neurosci. 39, 503-518. doi: 10.1523/JNEUROSCI.0537-18.2018

Mameli-Engvall, M., Evrard, A., Pons, S., Maskos, U., Svensson, T. H., Changeux, J. P., et al. (2006). Hierarchical control of dopamine neuron-firing patterns by nicotinic receptors. Neuron 50, 911-921. doi: 10.1016/j.neuron. 2006.05.007

Mansvelder, H. D., and McGehee, D. S. (2000). Long-term potentiation of excitatory inputs to brain reward areas by nicotine. Neuron 27, 349-357. doi: 10.1016/s0896-6273(00)00042-8

Mao, D., Gallagher, K., and McGehee, D. S. (2011). Nicotine potentiation of excitatory inputs to ventral tegmental area dopamine neurons. J. Neurosci. 31, 6710-6720. doi: 10.1523/JNEUROSCI.5671-10.2011

Mao, C., Yuan, X., Zhang, H., Lv, J., Guan, J., Miao, L., et al. (2008). The effect of prenatal nicotine on mRNA of central cholinergic markers and hematological parameters in rat fetuses. Int. J. Dev Neurosci. 26, 467-475. doi: 10.1016/j. ijdevneu.2008.02.007

Marks, M. J., Pauly, J. R., Gross, S. D., Deneris, E. S., Hermans-Borgmeyer, I., Heinemann, S. F., et al. (1992). Nicotine binding and nicotinic receptor subunit RNA after chronic nicotine treatment. J. Neurosci. 12, 2765-2784. doi: 10.1523/JNEUROSCI.12-07-02765.1992

Marks, M. J., Stitzel, J. A., and Collins, A. C. (1987). Influence of kinetics of nicotine administration on tolerance development and receptor levels. Pharmacol. Biochem. Behav. 27, 505-512. doi: 10.1016/0091-3057(87) 90355-8

Matta, J. A., Gu, S., Davini, W. B., Lord, B., Siuda, E. R., Harrington, A. W., et al. (2017). NACHO mediates nicotinic acetylcholine receptor function throughout the brain. Cell Rep. 19, 688-696. doi: 10.1016/j.celrep.2017.04.008

McClure-Begley, T. D., Esterlis, I., Stone, K. L., Lam, T. T., Grady, S. R., Colangelo, C. M., et al. (2016). Evaluation of the nicotinic acetylcholine receptor-associated proteome at baseline and following nicotine exposure in human and mouse cortex. eNeuro 3:ENEURO.0166-16.2016. doi: 10.1523/ENEURO.0166-16.2016

McGehee, D. S., Heath, M. J., Gelber, S., Devay, P., and Role, L. W. (1995). Nicotine enhancement of fast excitatory synaptic transmission in CNS by presynaptic receptors. Science 269, 1692-1696. doi: 10.1126/science.7569895

McGranahan, T. M., Patzlaff, N. E., Grady, S. R., Heinemann, S. F., and Booker, T. K. (2011). $\alpha 4 \beta 2$ nicotinic acetylcholine receptors on dopaminergic neurons mediate nicotine reward and anxiety relief. J. Neurosci. 31, 10891-10902. doi: 10.1523/JNEUROSCI.0937-11.2011

Mineur, Y. S., Abizaid, A., Rao, Y., Salas, R., DiLeone, R. J., Gundisch, D., et al. (2011). Nicotine decreases food intake through activation of POMC neurons. Science 332, 1330-1332. doi: 10.1126/science.1201889
Miwa, J. M., Anderson, K. R., and Hoffman, K. M. (2019). Lynx prototoxins: roles of endogenous mammalian neurotoxin-like proteins in modulating nicotinic acetylcholine receptor function to influence complex biological processes. Front. Pharmacol. 10:343. doi: 10.3389/fphar.2019.00343

Miwa, J. M., Stevens, T. R., King, S. L., Caldarone, B. J., Ibanez-Tallon, I., Xiao, C., et al. (2006). The prototoxin lynx1 acts on nicotinic acetylcholine receptors to balance neuronal activity and survival in vivo. Neuron 51, 587-600. doi: 10.1016/j.neuron.2006.07.025

Mobascher, A., Rujescu, D., Mittelstrass, K., Giegling, I., Lamina, C., Nitz, B., et al. (2010). Association of a variant in the muscarinic acetylcholine receptor 2 gene (CHRM2) with nicotine addiction. Am. J. Med. Genet. B Neuropsychiatr. Genet. 153B, 684-690. doi: 10.1002/ajmg.b.31011

Moretti, M., Fasoli, F., Gotti, C., and Marks, M. J. (2018). Reduced $\alpha 4$ subunit expression in $\alpha 4^{+-}$and $\alpha 4^{+-} / \beta 2^{+-}$nicotinic acetylcholine receptors alters $\alpha 4 \beta 2$ subtype up-regulation following chronic nicotine treatment. $B r$. J. Pharmacol. 175, 1944-1956. doi: 10.1111/bph.13896

Morishita, H., Miwa, J. M., Heintz, N., and Hensch, T. K. (2010). Lynx1, a cholinergic brake, limits plasticity in adult visual cortex. Science 330, 1238-1240. doi: 10.1126/science. 1195320

$\mathrm{Mu}, \mathrm{P}$., and Huang, Y. H. (2019). Cholinergic system in sleep regulation of emotion and motivation. Pharmacol. Res. 143, 113-118. doi: 10.1016/j.phrs.2019. 03.013

Mukhopadhyay, P., Horn, K. H., Greene, R. M., and Michele Pisano, M. (2010). Prenatal exposure to environmental tobacco smoke alters gene expression in the developing murine hippocampus. Reprod. Toxicol. 29, 164-175. doi: 10.1016/j.reprotox.2009.12.001

Mulcahy, M. J., Huard, S. M., Paulo, J. A., Wang, J. H., McKinney, S., Henderson, B. J., et al. (2020). Brain region-specific nAChR and associated protein abundance alterations following chronic nicotine and/or menthol exposure. J. Proteome Res. 19, 36-48. doi: 10.1021/acs.jproteome.9b 00286

Mulle, C., Vidal, C., Benoit, P., and Changeux, J. P. (1991). Existence of different subtypes of nicotinic acetylcholine receptors in the rat habenulointerpeduncular system. J. Neurosci. 11, 2588-2597. doi: 10.1523/JNEUROSCI. 11-08-02588.1991

Müller Herde, A., Mihov, Y., Krämer, S. D., Mu, L., Adamantidis, A. Ametamey, S. M., et al. (2019). Chronic nicotine exposure alters metabotropic glutamate receptor 5: longitudinal pet study and behavioural assessment in rats. Neurotox. Res. 36, 806-816. doi: 10.1007/s12640-019-00055-5

Mychasiuk, R., Muhammad, A., Ilnytskyy, S., and Kolb, B. (2013). Persistent gene expression changes in NAc, $\mathrm{mPFC}$, and $\mathrm{OFC}$ associated with previous nicotine or amphetamine exposure. Behav. Brain Res. 256, 655-661. doi: 10.1016/j.bbr. 2013.09 .006

Namba, M. D., Kupchik, Y. M., Spencer, S. M., Garcia-Keller, C., Goenaga, J. G., Powell, G. L., et al. (2020). Accumbens neuroimmune signaling and dysregulation of astrocytic glutamate transport underlie conditioned nicotineseeking behavior. Addict. Biol. 25:e12797. doi: 10.1111/adb.12797

Nashmi, R., and Lester, H. A. (2006). CNS localization of neuronal nicotinic receptors. J. Mol. Neurosci. 30, 181-184. doi: 10.1385/JMN:30:1:181

Nashmi, R., Xiao, C., Deshpande, P., McKinney, S., Grady, S. R., Whiteaker, P., et al. (2007). Chronic nicotine specifically upregulates functional $\alpha 4^{*}$ nicotinic receptors: basis for both tolerance in midbrain and enhanced long-term potentiation in perforant path. J. Neurosci. 27, 8202-8218. doi: 10.1523/JNEUROSCI.2199-07.2007

Nestler, E. J., Barrot, M., and Self, D. W. (2001). FosB: a sustained molecular switch for addiction. Proc. Natl. Acad. Sci. U S A 98, 11042-11046. doi: 10.1073/pnas. 191352698

Nichols, W. A., Henderson, B. J., Yu, C., Parker, R. L., Richards, C. I., Lester, H. A., et al. (2014). Lynx1 shifts $\alpha 4 \beta 2$ nicotinic receptor subunit stoichiometry by affecting assembly in the endoplasmic reticulum. J. Biol. Chem. 289, 31423-31432. doi: 10.1074/jbc.M114.573667

Ortiz, J. A., Castillo, M., del Toro, E. D., Mulet, J., Gerber, S., Valor, L. M., et al. (2005). The cysteine-rich with EGF-like domains 2 (CRELD2) protein interacts with the large cytoplasmic domain of human neuronal nicotinic acetylcholine receptor $\alpha 4$ and $\beta 2$ subunits. J. Neurochem. 95, 1585-1596. doi: 10.1111/j.14714159.2005.03473.x

Panagis, G., Kastellakis, A., Spyraki, C., and Nomikos, G. (2000). Effects of methyllycaconitine (MLA), an $\alpha 7$ nicotinic receptor antagonist, on 
nicotine- and cocaine-induced potentiation of brain stimulation reward. Psychopharmacology 149, 388-396. doi: 10.1007/s002130000384

Pang, X., Liu, L., Ngolab, J., Zhao-Shea, R., McIntosh, J. M., Gardner, P. D., et al. (2016). Habenula cholinergic neurons regulate anxiety during nicotine withdrawal via nicotinic acetylcholine receptors. Neuropharmacology 107, 294-304. doi: 10.1016/j.neuropharm.2016.03.039

Pankratov, Y., and Lalo, U. (2014). Calcium permeability of ligand-gated $\mathrm{Ca}^{2+}$ channels. Eur. J. Pharmacol. 739, 60-73. doi: 10.1016/j.ejphar.2013. 11.017

Park, S., Frisén, J., and Barbacid, M. (1997). Aberrant axonal projections in mice lacking EphA8 (Eek) tyrosine protein kinase receptors. EMBO J. 16, 3106-3114. doi: 10.1093/emboj/16.11.3106

Parker, R. L., O’Neill, H. C., Henley, B. M., Wageman, C. R., Drenan, R. M., Marks, M. J., et al. (2017). Deletion of lynx1 reduces the function of $\alpha 6^{*}$ nicotinic receptors. PLoS One 12:e0188715. doi: 10.1371/journal.pone. 0188715

Philibert, R. A., Gunter, T. D., Beach, S. R. H., Brody, G. H., and Madan, A. (2008). MAOA methylation is associated with nicotine and alcohol dependence in women. Am. J. Med. Genet. B Neuropsychiatr. Genet. 147B, 565-570. doi: 10.1002/ajmg.b.30778

Picciotto, M. R. (1998). Common aspects of the action of nicotine and other drugs of abuse. Drug Alcohol Depend. 51, 165-172. doi: 10.1016/s03768716(98)00074-x

Picciotto, M. R., Addy, N. A., Mineur, Y. S., and Brunzell, D. H. (2008). It is not "either/or": activation and desensitization of nicotinic acetylcholine receptors both contribute to behaviors related to nicotine addiction and mood. Prog. Neurobiol. 84, 329-342. doi: 10.1016/j.pneurobio.2007.12.005

Picciotto, M. R., Brunzell, D. H., and Caldarone, B. J. (2002). Effect of nicotine and nicotinic receptors on anxiety and depression. Neuroreport 13, 1097-1106. doi: 10.1097/00001756-200207020-00006

Picciotto, M. R., and Mineur, Y. S. (2013). Nicotine, food intake, and activation of POMC neurons. Neuropsychopharmacology 38:245. doi: 10.1038/npp.2012.163

Picciotto, M. R., and Zoli, M. (2002). Nicotinic receptors in aging and dementia. J. Neurobiol. 53, 641-655. doi: 10.1002/neu.10102

Picciotto, M. R., Zoli, M., Rimondini, R., Léna, C., Marubio, L. M., Pich, E. M., et al. (1998). Acetylcholine receptors containing the $\beta 2$ subunit are involved in the reinforcing properties of nicotine. Nature 391, 173-177. doi: 10.1038/ 34413

Pickens, C. L., Airavaara, M., Theberge, F., Fanous, S., Hope, B. T., and Shaham, Y. (2011). Neurobiology of the incubation of drug craving. Trends Neurosci. 34, 411-420. doi: 10.1016/j.tins.2011. 06.001

Pittenger, S. T., Schaal, V. L., Moore, D., Guda, R. S., Koul, S., Yelamanchili, S. V., et al. (2018). MicroRNA cluster miR199a/214 are differentially expressed in female and male rats following nicotine self-administration. Sci. Rep. 8:17464. doi: 10.1038/s41598-018-35747-z

Polesskaya, O. O., Fryxell, K. J., Merchant, A. D., Locklear, L. L., Ker, K.-F., McDonald, C. G., et al. (2007). Nicotine causes age-dependent changes in gene expression in the adolescent female rat brain. Neurotoxicol. Teratol. 29, 126-140. doi: 10.1016/j.ntt.2006.11.005

Pons, S., Fattore, L., Cossu, G., Tolu, S., Porcu, E., McIntosh, J. M., et al. (2008). Crucial role of $\alpha 4$ and $\alpha 6$ nicotinic acetylcholine receptor subunits from ventral tegmental area in systemic nicotine self-administration. J. Neurosci. 28, 12318-12327. doi: 10.1523/JNEUROSCI.3918-08.2008

Portugal, G. S., and Gould, T. J. (2009). Nicotine withdrawal disrupts new contextual learning. Pharmacol. Biochem. Behav. 92, 117-123. doi: 10.1016/j. pbb.2008.11.001

Pushkin, A. N., Eugene, A. J., Lallai, V., Torres-Mendoza, A., Fowler, J. P., Chen, E., et al. (2019). Cannabinoid and nicotine exposure during adolescence induces sex-specific effects on anxiety- and reward-related behaviors during adulthood. PLoS One 14:e0211346. doi: 10.1371/journal.pone.0211346

Quik, M., Perez, X. A., and Grady, S. R. (2011). Role of $\alpha 6$ nicotinic receptors in CNS dopaminergic function: relevance to addiction and neurological disorders. Biochem. Pharmacol. 82, 873-882. doi: 10.1016/j.bcp.2011.06.001

Rajan, S., Jang, Y., Kim, C.-H., Kim, W., Toh, H. T., Jeon, J., et al. (2020). PGE1 and PGA1 bind to Nurr1 and activate its transcriptional function. Nat. Chem. Biol. 16, 876-886. doi: 10.1038/s41589-020-0553-6
Rauh, V., Whyatt, R. M., Garfinkel, R., Andrews, H., Hoepner, L., Reyes, A., et al. (2004). Developmental effects of exposure to environmental tobacco smoke and material hardship among inner-city children. Neurotoxicol. Teratol. 26, 373-385. doi: 10.1016/j.ntt.2004.01.002

Ren, T., and Sagar, S. M. (1992). Induction of c-fos immunostaining in the rat brain after the systemic administration of nicotine. Brain Res. Bull. 29, 589-597. doi: 10.1016/0361-9230(92)90127-j

Renda, A., and Nashmi, R. (2014). Chronic nicotine pretreatment is sufficient to upregulate $\alpha 4^{*}$ nicotinic receptors and increase oral nicotine self-administration in mice. BMC Neurosci. 15:89. doi: 10.1186/1471-22 02-15-89

Rice, M. E., and Cragg, S. J. (2004). Nicotine amplifies reward-related dopamine signals in striatum. Nat. Neurosci. 7, 583-584. doi: 10.1038/nn1244

Richmond, R. C., Suderman, M., Langdon, R., Relton, C. L., and Davey Smith, G. (2018). DNA methylation as a marker for prenatal smoke exposure in adults. Int. J. Epidemiol. 47, 1120-1130. doi: 10.1093/ije/dyy091

Romoli, B., Lozada, A. F., Sandoval, I. M., Manfredsson, F. P., Hnasko, T. S., Berg, D. K., et al. (2019). Neonatal nicotine exposure primes midbrain neurons to a dopaminergic phenotype and increases adult drug consumption. Biol. Psychiatry 86, 344-355. doi: 10.1016/j.biopsych.2019.04.019

Rothhut, B., Romano, S. J., Vijayaraghavan, S., and Berg, D. K. (1996). Posttranslational regulation of neuronal acetylcholine receptors stably expressed in a mouse fibroblast cell line. J. Neurobiol. 29, 115-125. doi: 10.1002/(SICI)10974695(199601)29:1<115::AID-NEU9>3.0.CO;2-E

Ryan, R. E., and Loiacono, R. E. (2001). Nicotine regulates $\alpha 7$ nicotinic receptor subunit mRNA: implications for nicotine dependence. Neuroreport 12 , 569-572. doi: 10.1097/00001756-200103050-00027

Saccone, N. L., Wang, J. C., Breslau, N., Johnson, E. O., Hatsukami, D., Saccone, S. F., et al. (2009). The CHRNA5-CHRNA3-CHRNB4 nicotinic receptor subunit gene cluster affects risk for nicotine dependence in African-Americans and in European-Americans. Cancer Res. 69, 6848-6856. doi: 10.1158/0008-5472.CAN-09-0786

Salas, R., Sturm, R., Boulter, J., and De Biasi, M. (2009). Nicotinic receptors in the habenulo-interpeduncular system are necessary for nicotine withdrawal in mice. J. Neurosci. 29, 3014-3018. doi: 10.1523/JNEUROSCI.4934-08.2009

Schochet, T. L., Bremer, Q. Z., Brownfield, M. S., Kelley, A. E., and Landry, C. F. (2008). The dendritically targeted protein Dendrin is induced by acute nicotine in cortical regions of adolescent rat brain. Eur. J. Neurosci. 28, 1967-1979. doi: 10.1111/j.1460-9568.2008.06483.x

Schochet, T. L., Kelley, A. E., and Landry, C. F. (2005). Differential expression of arc mRNA and other plasticity-related genes induced by nicotine in adolescent rat forebrain. Neuroscience 135, 285-297. doi: 10.1016/j.neuroscience.2005. 05.057

Semick, S. A., Collado-Torres, L., Markunas, C. A., Shin, J. H., Deep-Soboslay, A., Tao, R., et al. (2018). Developmental effects of maternal smoking during pregnancy on the human frontal cortex transcriptome. Mol. Psychiatry 135, 285-297. doi: 10.1038/s41380-018-0223-1

Serot, J. M., Christmann, D., Dubost, T., and Couturier, M. (1997). Cerebrospinal fluid transthyretin: aging and late onset alzheimer's disease. J. Neurol. Neurosurg. Psychiatry 63, 506-508. doi: 10.1136/jnnp.63.4.506

Sharma, M., Khan, S., Rahman, S., and Singh, L. R. (2019). The extracellular protein, transthyretin is an oxidative stress biomarker. Front. Physiol. 10:5. doi: 10.3389/fphys.2019.00005

Sharp, B. M., Beyer, H. S., McAllen, K. M., Hart, D., and Matta, S. G. (1993). Induction and desensitization of the c-Fos mRNA response to nicotine in rat brain. Mol. Cell. Neurosci. 4, 199-208. doi: 10.1006/mcne.1993.1024

Sheffield, E. B., Quick, M. W., and Lester, R. A. J. (2000). Nicotinic acetylcholine receptor subunit mRNA expression and channel function in medial habenula neurons. Neuropharmacology 39, 2591-2603. doi: 10.1016/s00283908(00)00138-6

Sheng, M., and Greenberg, M. E. (1990). The regulation and function of c-fos and other immediate early genes in the nervous system. Neuron 4, 477-485. doi: 10.1016/0896-6273(90)90106-p

Sherafat, Y., Bautista, M., Fowler, J. P., Chen, E., Ahmed, A., and Fowler, C. D. (2020). The interpeduncular-ventral hippocampus pathway mediates active stress coping and natural reward. eNeuro 7:ENEURO.0191-20.2020. doi: 10.1523/ENEURO.0191-20.2020 
Sonntag, S., Söhl, G., Dobrowolski, R., Zhang, J., Theis, M., Winterhager, E., et al. (2009). Mouse lens connexin23 (Gje1) does not form functional gap junction channels but causes enhanced ATP release from HeLa cells. Eur. J. Cell Biol. 88, 65-77. doi: 10.1016/j.ejcb.2008.08.004

Srinivasan, R., Pantoja, R., Moss, F. J., Mackey, E. D., Son, C. D., Miwa, J., et al. (2011). Nicotine up-regulates $\alpha 4 \beta 2$ nicotinic receptors and ER exit sites via stoichiometry-dependent chaperoning. J. Gen. Physiol. 137, 59-79. doi: 10.1085/jgp.201010532

Staley, J. K., Krishnan-Sarin, S., Cosgrove, K. P., Krantzler, E., Frohlich, E., Perry, E., et al. (2006). Human tobacco smokers in early abstinence have higher levels of $\beta 2^{*}$ nicotinic acetylcholine receptors than nonsmokers. J. Neurosci. 26, 8707-8714. doi: 10.1523/JNEUROSCI.0546-06.2006

Sun, H.-J., Jia, Y.-F., and Ma, X.-L. (2017). $\alpha 5$ nicotinic acetylcholine receptor contributes to nicotine-induced lung cancer development and progression. Front. Pharmacol. 8:573. doi: 10.3389/fphar.2017.00573

Tapper, A. R., McKinney, S. L., Nashmi, R., Schwarz, J., Deshpande, P., Labarca, C., et al. (2004). Nicotine activation of $\alpha 4^{*}$ receptors: sufficient for reward, tolerance, and sensitization. Science 306, 1029-1032. doi: 10.1126/science. 1099420

Tehranifar, P., Wu, H.-C., McDonald, J. A., Jasmine, F., Santella, R. M., Gurvich, I., et al. (2018). Maternal cigarette smoking during pregnancy and offspring DNA methylation in midlife. Epigenetics 13, 129-134. doi: 10.1080/15592294.2017. 1325065

Tekinay, A. B., Nong, Y., Miwa, J. M., Lieberam, I., Ibanez-Tallon, I., Greengard, P., et al. (2009). A role for LYNX2 in anxiety-related behavior. Proc. Natl. Acad. Sci. U S A 106, 4477-4482. doi: 10.1073/pnas.0813109106

Theile, J. W., Morikawa, H., Gonzales, R. A., and Morrisett, R. A. (2008). Ethanol enhances GABAergic transmission onto dopamine neurons in the ventral tegmental area of the rat. Alcohol. Clin. Exp. Res. 32, 1040-1048. doi: 10.1111/j. 1530-0277.2008.00665.x

Thomsen, M. S., Cinar, B., Jensen, M. M., Lyukmanova, E. N., Shulepko, M. A., Tsetlin, V., et al. (2014). Expression of the Ly-6 family proteins Lynx1 and Ly6H in the rat brain is compartmentalized, cell-type specific, and developmentally regulated. Brain Struct. Funct. 219, 1923-1934. doi: 10.1007/s00429-0130611-x

Thomsen, M., Sørensen, G., and Dencker, D. (2018). Physiological roles of CNS muscarinic receptors gained from knockout mice. Neuropharmacology 136, 411-420. doi: 10.1016/j.neuropharm.2017.09.011

Tornesello, M. L., Faraonio, R., Buonaguro, L., Annunziata, C., Starita, N., Cerasuolo, A., et al. (2020). The role of microRNAs, long non-coding RNAs, and circular RNAs in cervical cancer. Front. Oncol. 10:150. doi: 10.3389/fonc. 2020.00150

Tuesta, L. M., Chen, Z., Duncan, A., Fowler, C. D., Ishikawa, M., Lee, B. R., et al. (2017). GLP-1 acts on habenular avoidance circuits to control nicotine intake. Nat. Neurosci. 20, 708-716. doi: 10.1038/nn.4540

Turner, J. R., Ray, R., Lee, B., Everett, L., Xiang, J., Jepson, C., et al. (2014a). Evidence from mouse and man for a role of neuregulin 3 in nicotine dependence. Mol. Psychiatry 19, 801-810. doi: 10.1038/mp. 2013.104

Turner, C. A., Thompson, R. C., Bunney, W. E., Schatzberg, A. F., Barchas, J. D., Myers, R. M., et al. (2014b). Altered choroid plexus gene expression in major depressive disorder. Front. Hum. Neurosci. 8:238. doi: 10.3389/fnhum.2014. 00238

Ugur, M., Kaya, E., Gozen, O., Koylu, E. O., Kanit, L., Keser, A., et al. (2017). Chronic nicotine-induced changes in gene expression of $\delta$ and $\kappa$-opioid receptors and their endogenous ligands in the mesocorticolimbic system of the rat. Synapse 71:e21985. doi: 10.1002/syn.21985

Vieyra-Reyes, P., Picciotto, M. R., and Mineur, Y. S. (2008). Voluntary oral nicotine intake in mice down-regulates GluR2 but does not modulate depression-like behaviors. Neurosci. Lett. 434, 18-22. doi: 10.1016/j.neulet. 2008.01.021

Visanji, N. P., Mitchell, S. N., O'Neill, M. J., and Duty, S. (2006). Chronic pre-treatment with nicotine enhances nicotine-evoked striatal dopamine release and $\alpha 6$ and $\beta 3$ nicotinic acetylcholine receptor subunit mRNA in the substantia nigra pars compacta of the rat. Neuropharmacology 50, 36-46. doi: 10.1016/j.neuropharm.2005.07.013

Wang, H., and Sun, X. (2005). Desensitized nicotinic receptors in brain. Brain Res. Rev. 48, 420-437. doi: 10.1016/j.brainresrev.2004.09.003
Wan, C., Yang, Y., Li, H., La, Y., Zhu, H., Jiang, L., et al. (2006). Dysregulation of retinoid transporters expression in body fluids of schizophrenia patients. J. Proteome Res. 5, 3213-3216. doi: 10.1021/pr0601761

Wang, Y., Yao, Y., Tang, X.-Q., and Wang, Z. Z. (2009). Mouse RIC-3, an endoplasmic reticulum chaperone, promotes assembly of the $\alpha 7$ acetylcholine receptor through a cytoplasmic coiled-coil domain. J. Neurosci. 29, 12625-12635. doi: 10.1523/JNEUROSCI.1776-09.2009

Wang, K. S., Zegel, M., Molokotos, E., Moran, L. V., Olson, D. P., Pizzagalli, D. A., et al. (2020). The acute effects of nicotine on corticostriatal responses to distinct phases of reward processing. Neuropsychopharmacology 45, 1207-1214. doi: 10.1038/s41386-020-0611-5

Wecker, L., Pollock, V. V., Pacheco, M. A., and Pastoor, T. (2010). Nicotineinduced up regulation of $\alpha 4 \beta 2$ neuronal nicotinic receptors is mediated by the protein kinase C-dependent phosphorylation of $\alpha 4$ subunits. Neuroscience 171, 12-22. doi: 10.1016/j.neuroscience.2010.09.005

Wess, J., Eglen, R. M., and Gautam, D. (2007). Muscarinic acetylcholine receptors: mutant mice provide new insights for drug development. Nat. Rev. Drug Discov. 6, 721-733. doi: 10.1038/nrd2379

West, R. (2006). Theory of Addiction. Malden, MA: Blackwell/Addiction Press.

Wiklund, P., Karhunen, V., Richmond, R. C., Parmar, P., Rodriguez, A., De Silva, M., et al. (2019). DNA methylation links prenatal smoking exposure to later life health outcomes in offspring. Clin. Epigenetics 11:97. doi: 10.1186/s13148-019-0683-4

Wittenberg, R. E., Wolfman, S. L., De Biasi, M., and Dani, J. A. (2020). Nicotinic acetylcholine receptors and nicotine addiction: a brief introduction. Neuropharmacology 177:108256. doi: 10.1016/j.neuropharm.2020.108256

Wolfman, S. L., Gill, D. F., Bogdanic, F., Long, K., Al-Hasani, R., McCall, J. G., et al. (2018). Nicotine aversion is mediated by GABAergic interpeduncular nucleus inputs to laterodorsal tegmentum. Nat. Commun. 9:2710. doi: 10.1038/s41467018-04654-2

Wu, M., Puddifoot, C. A., Taylor, P., and Joiner, W. J. (2015). Mechanisms of inhibition and potentiation of $\alpha 4 \beta 2$ nicotinic acetylcholine receptors by members of the Ly6 protein family. J. Biol. Chem. 290, 24509-24518. doi: 10.1074/jbc.M115.647248

Xue, Y.-X., Chen, Y.-Y., Zhang, L.-B., Zhang, L.-Q., Huang, G.-D., Sun, S.-C., et al. (2017). Selective inhibition of amygdala neuronal ensembles encoding nicotine-associated memories inhibits nicotine preference and relapse. Biol. Psychiatry 82, 781-793. doi: 10.1016/j.biopsych.2017.04.017

Yagi, S., Tanida, M., and Satomi, J. (2015). Possible role of afferent autonomic signals in abdominal organs in anorexic and cardiovascular responses to nicotine injection in rats. Neuroreport 26, 445-449. doi: 10.1097/WNR. 0000000000000361

Yamasaki, M., Matsui, M., and Watanabe, M. (2010). Preferential localization of muscarinic M1 receptor on dendritic shaft and spine of cortical pyramidal cells and its anatomical evidence for volume transmission. J. Neurosci. 30, 4408-4418. doi: 10.1523/JNEUROSCI.5719-09.2010

Yan, Y., Beckley, N. A., Kim, V. J., and Drenan, R. M. (2019). Differential nicotinic modulation of glutamatergic and GABAergic VTA microcircuits. eNeuro 6:ENEURO.0298-19.2019. doi: 10.1523/ENEURO.0298-19.2019

Yu, G., Chen, H., Zhao, W., Matta, S. G., and Sharp, B. M. (2008). Nicotine self-administration differentially regulates hypothalamic corticotropinreleasing factor and arginine vasopressin mRNAs and facilitates stress-induced neuronal activation. J. Neurosci. 28, 2773-2782. doi: 10.1523/JNEUROSCI. 3837-07.2008

Zdenek, C. N., Harris, R. J., Kuruppu, S., Youngman, N. J., Dobson, J. S., Debono, J., et al. (2019). A taxon-specific and high-throughput method for measuring ligand binding to nicotinic acetylcholine receptors. Toxins 11:600. doi: 10.3390/toxins 11100600

Zhang, H., Kranzler, H. R., Poling, J., and Gelernter, J. (2010). Variation in the nicotinic acetylcholine receptor gene cluster CHRNA5-CHRNA3CHRNB4 and its interaction with recent tobacco use influence cognitive flexibility. Neuropsychopharmacology 35, 2211-2224. doi: 10.1038/npp.2010.95

Zhao-Shea, R., Degroot, S. R., Liu, L., Vallaster, M., Pang, X., Su, Q., et al. (2015). Increased CRF signalling in a ventral tegmental area-interpeduncular nucleus-medial habenula circuit induces anxiety during nicotine withdrawal. Nat. Commun. 6:6770. doi: 10.1038/ncomms7770

Zhao-Shea, R., Liu, L., Pang, X., Gardner, P. D., and Tapper, A. R. (2013). Activation of GABAergic neurons in the interpeduncular nucleus 
triggers physical nicotine withdrawal symptoms. Curr. Biol. 23, 2327-2335. doi: 10.1016/j.cub.2013.09.041

Zhou, L., Fisher, M. L., Cole, R. D., Gould, T. J., Parikh, V., Ortinski, P. I., et al. (2018). Neuregulin 3 signaling mediates nicotine-dependent synaptic plasticity in the orbitofrontal cortex and cognition. Neuropsychopharmacology 43, 1343-1354. doi: 10.1038/npp. 2017.278

Zhu, H., Lee, M., Agatsuma, S., and Hiroi, N. (2007). Pleiotropic impact of constitutive fosB inactivation on nicotine-induced behavioral alterations and stress-related traits in mice. Hum. Mol. Genet. 16, 820-836. doi: $10.1093 / \mathrm{hmg} / \mathrm{ddm} 027$
Conflict of Interest: The authors declare that the research was conducted in the absence of any commercial or financial relationships that could be construed as a potential conflict of interest.

Copyright (c) 2021 Sherafat, Bautista and Fowler. This is an open-access article distributed under the terms of the Creative Commons Attribution License (CC BY). The use, distribution or reproduction in other forums is permitted, provided the original author(s) and the copyright owner(s) are credited and that the original publication in this journal is cited, in accordance with accepted academic practice. No use, distribution or reproduction is permitted which does not comply with these terms. 